\title{
Lithospheric-scale buckling and thrust structures on Mars: The Coprates rise and south Tharsis ridge belt
}

\author{
Richard A. Schultz \\ Geomechanics-Rock Fracture Group, \\ Department of Geological Sciences, Mackay School of Mines, University of Nevada, Reno
}

\author{
Kenneth L. Tanaka \\ U.S. Geological Survey, Flagstaff, Arizona
}

\begin{abstract}
Detailed photogeologic mapping documents for the first time the deformation sequence of the Coprates rise. Materials of Middle Noachian through perhaps Early Hesperian age were involved in the horizontal shortening of crustal and lithospheric rocks that produced uplift and asymmetric, east-vergent folding of these layers during the Late Noachian and perhaps Early Hesperian. Previous suggestions of normal faulting as the deforming mechanism are not supported by the new mapping or by dislocation models of rise topography. The most likely mechanism for producing the Coprates rise is folding due to buckling instability and perhaps thrust faulting. An extensive ridge belt concentric to south Tharsis is defined by a newly recognized system of approximately coeval longwavelength topographic ridges and swales that include the Coprates rise. Horizontal shortening of crust and lithosphere is manifested by periodically spaced structures at two different scales: wrinkle ridges spaced tens of kilometers apart and the south Tharsis system of ridges spaced hundreds of kilometers apart. Both types of structures may be associated with early volcanotectonic activity and crustal thickening in south Tharsis. These and other large ridges indicate that lithospheric buckling and thrust faulting may have been common on early Mars.
\end{abstract}

\section{Introduction and Summary}

The Coprates rise is a north-trending, east-vergent, asymmetric anticline that extends for $\sim 900 \mathrm{~km}$ south of Valles Marineris. It is composed of Middle to Upper Noachian intercrater plains materials that were deformed during Late Noachian and perhaps Early Hesperian time. The east flank of the rise is steeper than the west flank, and both show clear exposures of tilted beds that conform to the rise's topography. The rise is embayed by ridged plains material that may also be deformed along its edges, suggesting that uplift and folding associated with formation of the rise may have continued into the Early Hesperian. Comparisons of reconstructed topography of the rise with profiles calculated from models of normal- and thrust-fault dislocation indicate that normal faulting was not the primary mechanism that produced the Coprates rise. Instead, folding associated with buckling instability (perhaps also a component of thrust faulting) was the most likely mechanism.

The rise is part of a broad, arcuate belt of ridges and scarps that spans a region 2500 by $6000 \mathrm{~km}$. The belt contains -28 other structures of similar age that are associated with the western, southern, and eastern margins of south Tharsis. The spacing of $150-500 \mathrm{~km}$ perpendicular to trend between most of

Copyright 1994 by the American Geophysical Union.

Paper number 94JE00277.

$0148-0227 / 94 / 94 \mathrm{JE}-00277 \$ 05.00$ the ridges suggests that buckling of the lithosphere occurred in this region, apparently associated with an early stress center (near latitude (lat) $20^{\circ}-25^{\circ} \mathrm{S}$, longitude (long) $90^{\circ}$ ) in Solis Planum (Figure 1). Significant differences in development and trend between local wrinkle ridges and the ridges of the south Tharsis belt suggest that shallow wrinkle ridge fotmation was spatially associated with, but locally distinct from, formation of the south Tharsis ridge belt; this relation can be explained by partial decoupling of shallow layers from deeper ones. Major contractional deformation in southern Tharsis was an early stage of the volcanotectonic growth of the Tharsis region as a whole. Because the regular long-wavelength topography does not continue north of the younger Valles Marineris troughs, it is likely that Lunae Planum and the Thaumasia plateau were characterized by distinct crustal/lithospheric structure or stress states during the Late Noachian that might have contributed to subsequent localization of high topography and lithospheric rifting.

Other sets of large ridge-and-scarp structures occur elsewhere on Mars at Phlegra Montes and west of Arcadia Planitia, at Mareotis Fossae, at Amenthes Rupes, and east of the Hellas basin; all the structures appear to be Early Hesperian or older and may reflect contractional deformation similar to and contemporaneous with that in the south Tharsis ridge belt. Formation of prominent ridge-and-scarp belts in several locations on the planet by lithospheric buckling and perhaps thrust faulting apparently led to, or accommodated, local crustal thickening during early Martian geologic history. 


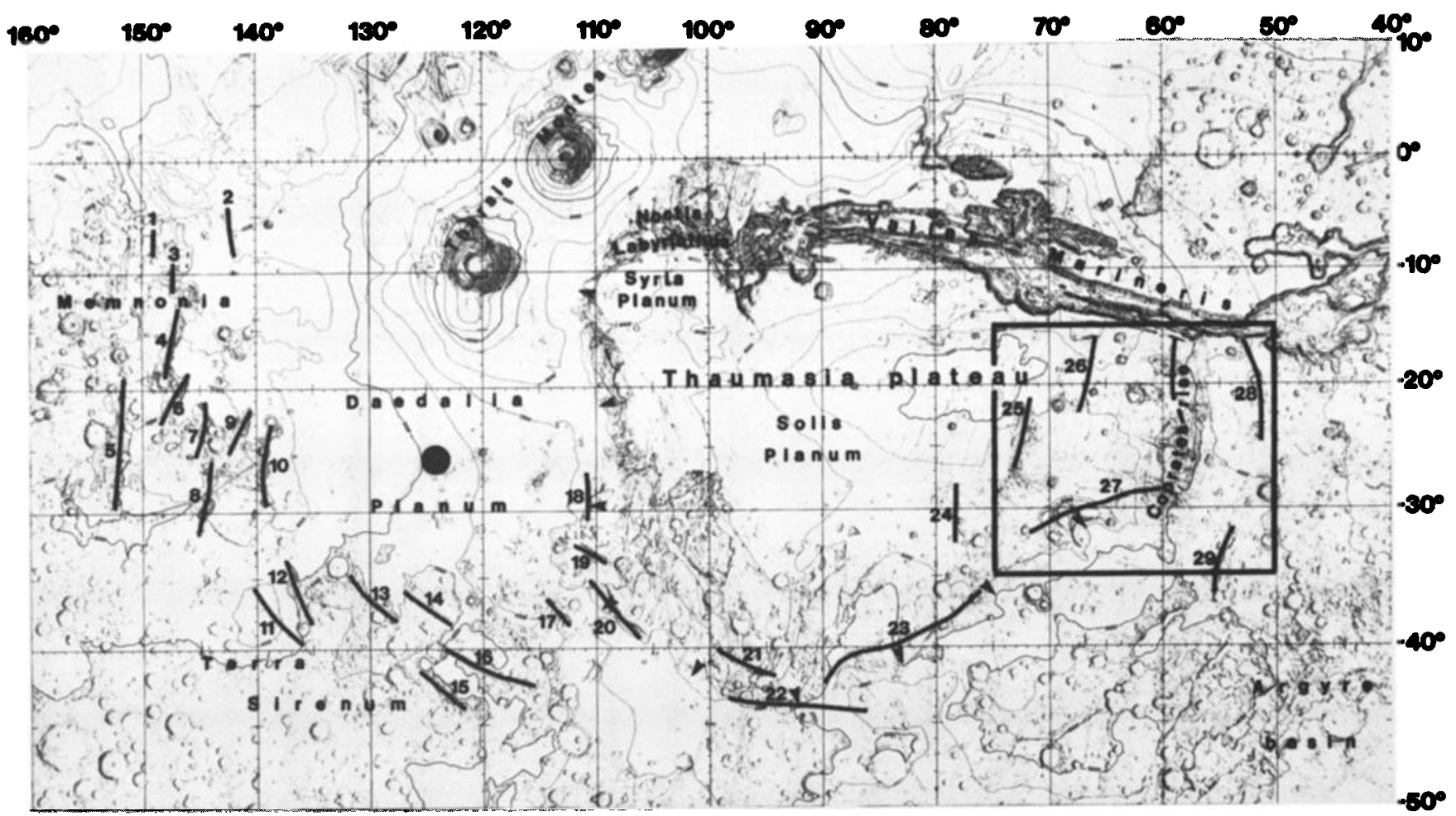

Figure 1. Shaded relief and topographic map (1-km contour interval) of the south Tharsis region showing major geographic features mentioned in text. Margins of Thaumasia plateau indicated by arrows; proposed contractional structures of south Tharsis ridge belt shown by numbered lines. Box outlines border of geologic map in Figure 2a. Large dot indicates center of proposed impact basin of Craddock et al. [1990].

\section{Background}

The Coprates rise is located south of Coprates Chasma (eastern Valles Marineris) between lat $16^{\circ}$ and $29^{\circ} \mathrm{S}$ and long $56^{\circ}$ and $63^{\circ}$ (Figures 1 and 2). The rise defines the eastern margin of the broad Thaumasia plateau that is some $3000 \mathrm{~km}$ across and about 1-3 km above surrounding terrain. Smaller rises and scarps form parts of the southern and western plateau margins (Figure 1). The northern edge of the plateau is cut by the troughs of Valles Marineris and Noctis Labyrinthus. Syria Planum, which makes up the northwestern part of the Thaumasia plateau, is a major, long-lived volcanotectonic province [Tanaka and Davis, 1988]. The Tharsis volcanotectonic region, which includes the Thaumasia plateau, is centered near Syria Planum and encompasses nearly a hemisphere of Mars [e.g., Wise et al., 1979].

Along the margins of the Thaumasia plateau, many degraded grabens and ridges indicate intense tectonic deformation early in Mars' geologic history [Frey, 1979; Plescia and Saunders, 1982; Scott and Tanaka, 1986]. Younger lavas of Hesperian age that form ridged plains and volcanic flow fields cover many parts of the plateau, as well as much of the surrounding high plains. Earth-based radar data for the northern part of the rise (Figure 3) show that its crest is about $1 \mathrm{~km}$ above the adjacent plateau to the west and $2-4 \mathrm{~km}$ above adjacent plains to the east. The rise is the largest of a series of topographic arches and swales on the Thaumasia plateau (Figures 1 and 2); the smaller arches on the plateau have less than $1 \mathrm{~km}$ of relief (Figure 3 ).

Saunders et al. [1980] proposed that the Coprates rise was formed by monoclinal folding, based on their observation of tilted layers on its east flank. They also suggested that the margin of the Thaumasia plateau as a whole may be the remnant of an ancient impact basin. Watters [1987] also proposed a compressional origin for the Coprates rise and adjoining smaller arches. His model involves buckling of the entire lithosphere, as inferred by the large spacing $(-400 \mathrm{~km})$ of the arches, perhaps as a result of Tharsis-centered stress. He further proposed that wrinkle ridges in the region having a typical spacing of several tens of kilometers were the result of thin-skinned deformation in the upper part of the lithosphere.

In contrast, Plescia et al. [1980] interpreted the rise and its bounding ridges to be faulted crustal blocks tilted to the west. Because of similar ridge topography west of the Tharsis region, they also mentioned that block (i.e., normal) faulting was related to regional tectonism or to a large impact basin centered in Daedalia Planum. Craddock et al. [1990] cited possible further evidence for such an impact basin and inferred its center's location (Figure 1, dot) and ring structures. However, their proposed outermost ring reaches only to long $68^{\circ}$, about $500 \mathrm{~km}$ west of the Coprates rise [cf. Craddock et al., 1990, Figure 8; Schultz and Frey, 1990].

Despite the significance of the Coprates rise as a major tectonic landform, the geologic and tectonic histories of the rise, the Thaumasia plateau, and the south Tharsis region are poorly understood and have received comparatively little attention, although Watters [1993] discussed some of them as examples of large-scale structures. Detailed studies of Martian tectonism have concentrated instead on the kinematics and development of Tharsis-related patterns of younger grabens and wrinkle ridges [e.g., Banerdt et al., 1982, 1992; Watters and Maxwell, 1986; 


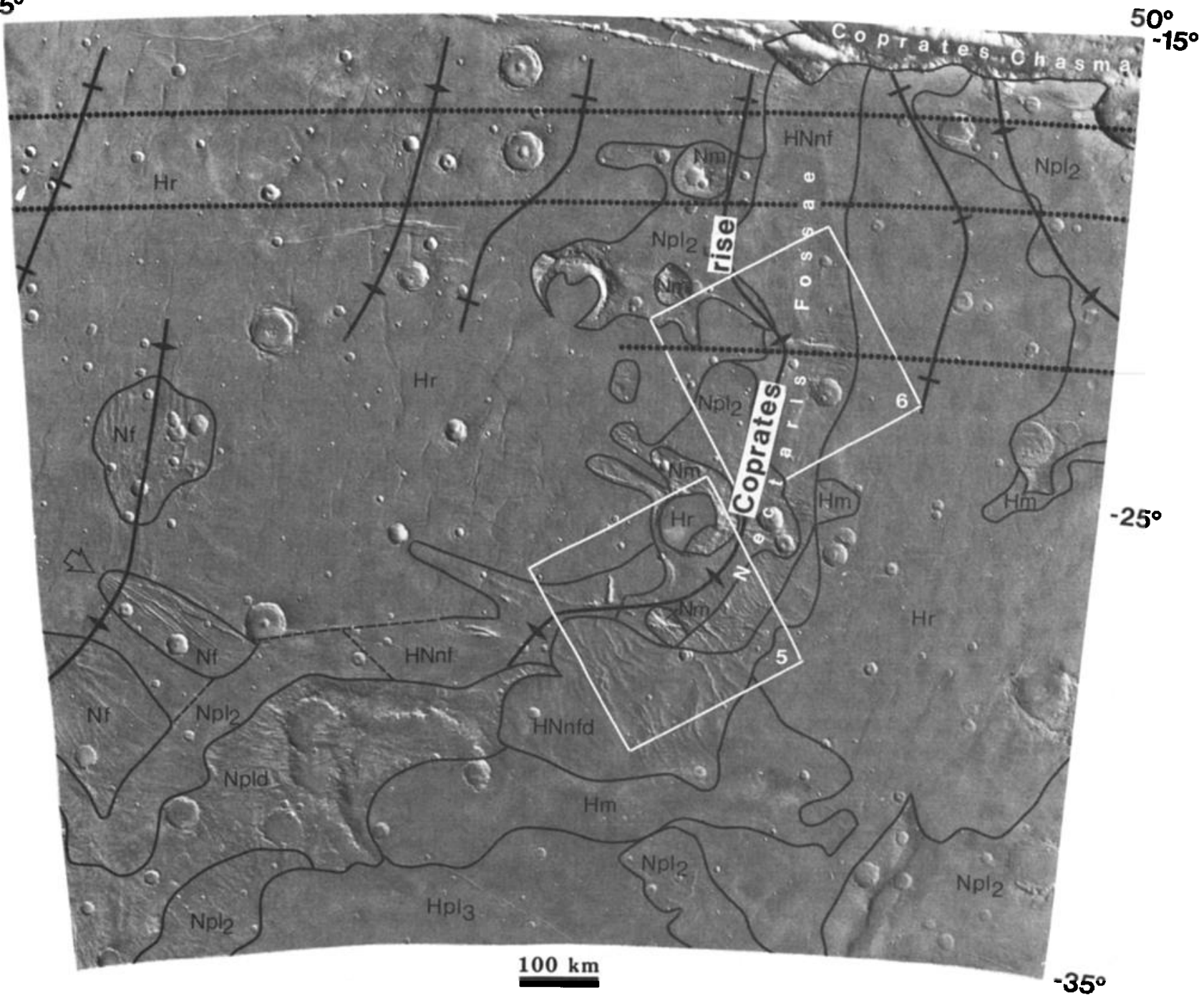

Figure 2a. Geologic map of the Coprates rise and vicinity. Geologic units include Nm, mountain material; Nf, fractured material; Npld, dissected plateau material; $\mathrm{Npl}_{2}$, intercrater plains material; $\mathrm{HNnf}$, faulted material of Nectaris Fossae; HNnfd, dissected material of Nectaris Fossae; $\mathrm{Hr}$, ridged plains material; Hpl 3 , smooth plains material; Hm, mantle material. Dashed contacts indicate gradational or uncertain boundaries. Broad ridges indicated by lines with diamonds; swales, by lines with bars. Arrows show intensely faulted, riftlike zones. Dotted lines show tracks of radar profiles shown in Figures 3 and 9. Boxes show locations of Figures 5 and 6.

Tanaka et al., 1991; Watters, 1991, 1993; Thomas and Allemand, 19931 and on the formation of the Valles Marineris [e.g., Schultz, 1991; Lucchitta et al., 1992].

\section{Geologic and Structural History of the Coprates Region}

We have determined geologic relations among the materials and structures of the Coprates rise and surrounding terrain (Figure 2a) through photogeologic mapping and crater counting on Viking images (Figure 4; Table 1). Helpful topographic data included radar profiles (Figure 3 ) and stereo image pairs. In this section we briefly describe the map units and structure that form a basis for interpreting the geologic and geomorphologic sequence, and we arrive at a structural history for the Coprates rise based on crater counts and stratigraphic relations. We attempted to be conservative in our mapping of large contractional landforms; we may have excluded comparable structures that are highly degraded or buried or that lack definitive topographic data.

\section{Stratigraphy}

We generally follow the previous mapping of Scott and Tanaka [1986]; in a few instances, we have modified the placement of contacts as well as unit names and symbols. Additionally, we have introduced three new units related to the Coprates rise, based on detailed inspection of available images. Crater diameters down to $1 \mathrm{~km}$ were measured digitally from medium-resolution (200-260 m/pixel) Viking images. The correlation chart (Figure $2 b$ ) shows the relative ages of these units. Many smaller craters on Noachian units, however, have been obliterated by later resurfacing (see Table 1 and Figure 4). Thus stratigraphic relations are more important than crater counts in the interpretation of their formational ages. 


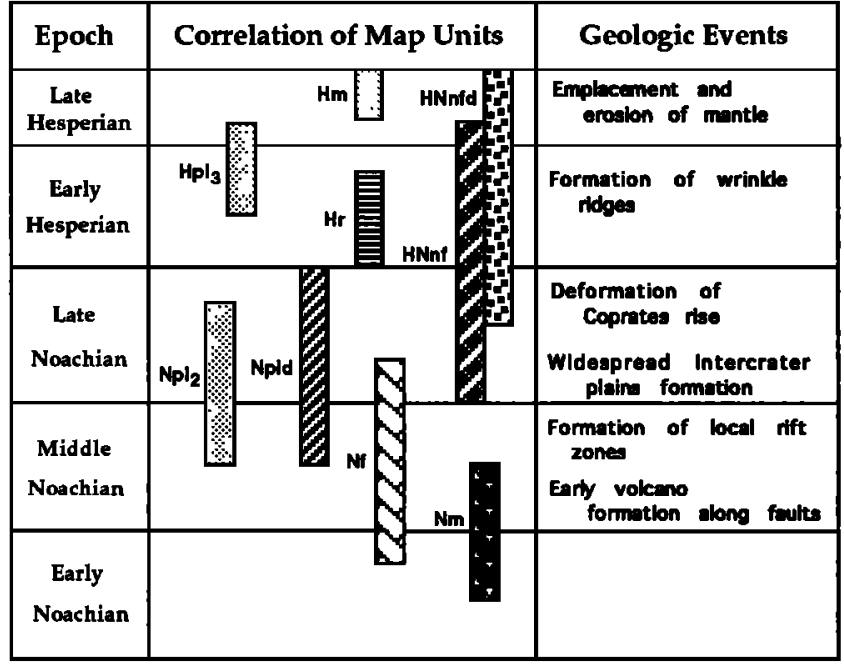

Figure 2b. Correlation of map units for Coprates rise region. Assignment of relative ages (epochs) and correlation with geologic events discussed in text.

The region's oldest materials (Middle Noachian) have been preserved as high-standing remnants. Areas of fractured material (unit Nf) in the western part of the map area are intensely cratered and cut by degraded, shallow linear grabens. Several large mountains along the west flank of the Coprates rise (unit Nm; see Figure 5) are possibly volcanic [Saunders et al., 1980; Scott and Tanaka, 1986]. In the southwestern part of the map area, dissected plateau material (unit Npld) forms a strip of rugged terrain delineating the margin of the Thaumasia plateau. Erosion, probably by groundwater sapping of poorly indurated materials, has resulted in pervasive, degraded valleys on the unit's hilly slopes. Much of the map area was probably resurfaced during the Late Noachian by volcanic materials erupted from local sources and by sedimentary deposits resulting from erosion of higher areas; these rocks are mapped as intercrater plains material (unit $\mathrm{Npl}_{2}$ ). On the rise, the unit is moderately deformed by a few narrow grabens and a northwesttrending riftlike structure (at lat $25^{\circ} \mathrm{S}$, long $61^{\circ}$ ) of Nectaris Fossae.
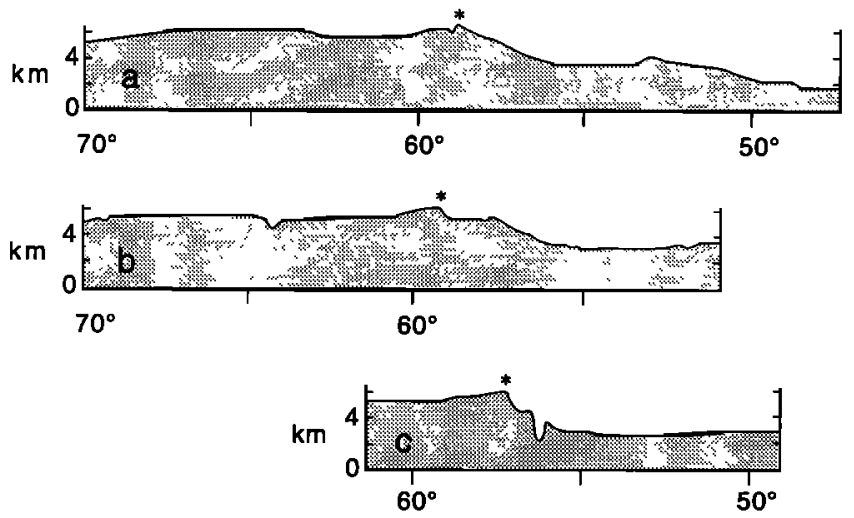

Figure 3. Topographic profiles of northern part of Coprates rise based on Earth-based radar altimetry [Roth et al,, 1980]. Tracks of profiles shown in Figure $2 \mathrm{a}$ at (a) $17^{\circ} \mathrm{S}$, (b) $19^{\circ} \mathrm{S}$, (c) $22^{\circ} \mathrm{S}$. Vertical exaggeration 23:1. Intersections with Coprates rise indicated by asterisks.

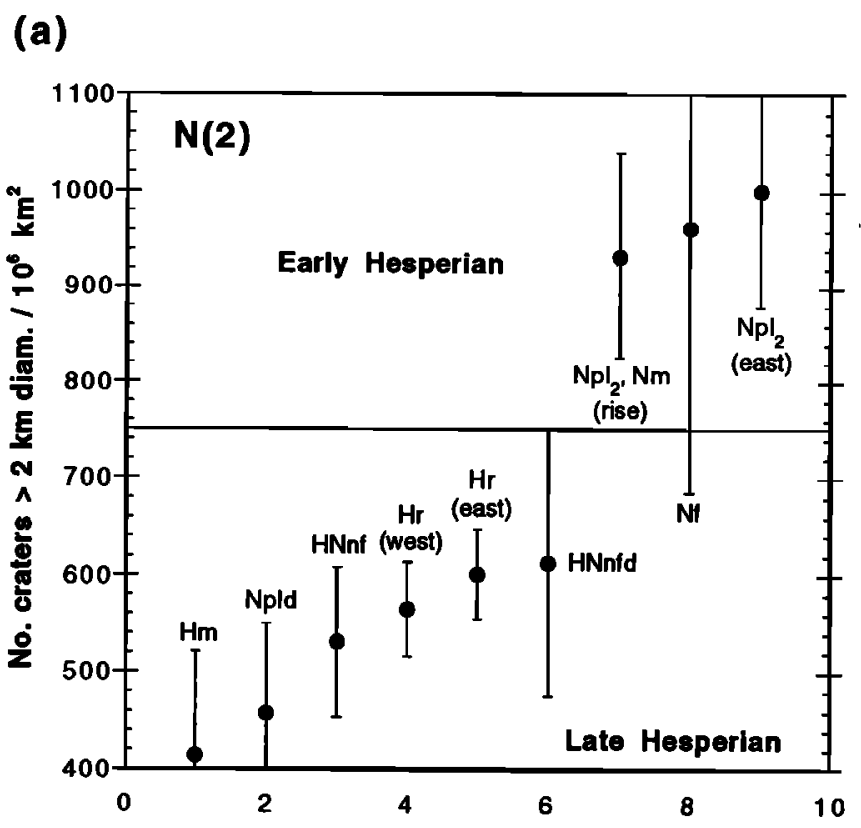

(b)

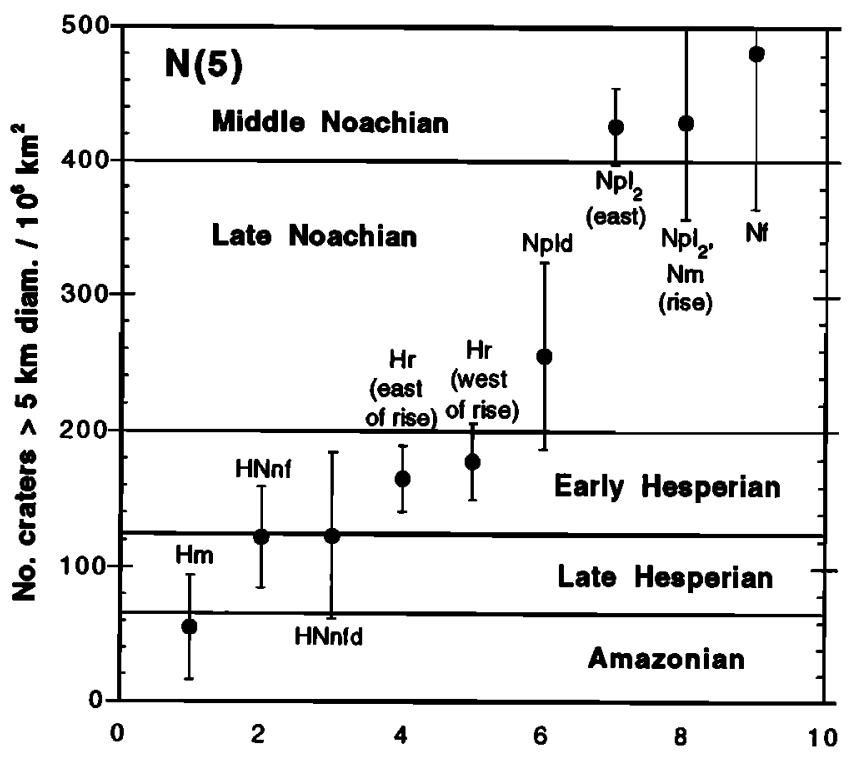

Figure 4. Cumulative crater densities of geologic units in the Coprates rise region. Data from Table 1; epoch boundaries from Tanaka [1986]. (a) Craters larger than $2 \mathrm{~km}$ in diameter. (b) Craters larger than $5 \mathrm{~km}$ in diameter.

Along the east flank of the Coprates rise, highly faulted material of Nectaris Fossae (unit HNnf) grades with intercrater plains material (unit $\mathrm{Npl}_{2}$ ) to the west and is embayed from the east by ridged plains (unit $\mathrm{Hr}$ ) and mantle (unit $\mathrm{Hm}$ ) materials (Figures 5 and 6). The faults and grabens trend mostly west and locally northwest. Along steeper slopes of the rise, erosion controlled by faults has produced triangular, faceted hogbacks from a layered sequence (Figure 5). The highly faulted material may be deformed intercrater plains material whose deep dissection on the crest and steeper flanks of the rise has removed many large impact craters. The unit also includes some flows that appear to fill north-trending grabens and depressions and possibly to bury ridged plains material (Figure 6). At the south 
Table 1. Cumulative Densities of Craters for Geologic Units in the Coprates Rise Region

\begin{tabular}{lccr}
\hline Unit & $\mathrm{N}(2)$ & $\mathrm{N}(5)$ & Area, $^{2}$ \\
\hline Hm & $414 \pm 107$ & $55 \pm 39$ & 36,274 \\
Hr, west & $565 \pm 49$ & $178 \pm 28$ & 235,357 \\
Hr, east & $601 \pm 46$ & $165 \pm 24$ & 279,628 \\
HNnf & $531 \pm 77$ & $122 \pm 37$ & 90,441 \\
HNnfd & $613 \pm 137$ & $123 \pm 61$ & 32,612 \\
Npld & $458 \pm 92$ & $256 \pm 69$ & 54,609 \\
Npl, Nm; rise & $933 \pm 107$ & $430 \pm 73$ & 81,434 \\
Npl ; east & $1001 \pm 121$ & $427 \pm 29$ & 67,956 \\
Nf & $963 \pm 277$ & $482 \pm 117$ & 35,297 \\
\hline
\end{tabular}

Data acquired for craters larger than 2 and $5 \mathrm{~km}$ in diameter per $10^{6} \mathrm{~km}^{2}(\mathrm{~N}(2)$ and $\mathrm{N}(5)$, respectively) from Viking images 606A44; 608A27, 28, and 32 and 610A21-29 and 41-46 at resolutions of 208 to $256 \mathrm{~m} / \mathrm{pixel}$.

end of the Coprates rise, the highly faulted unit is overlain by the dissected material of Nectaris Fossae (unit HNnfd). This unit is highly degraded and cut by channels originating from the crest

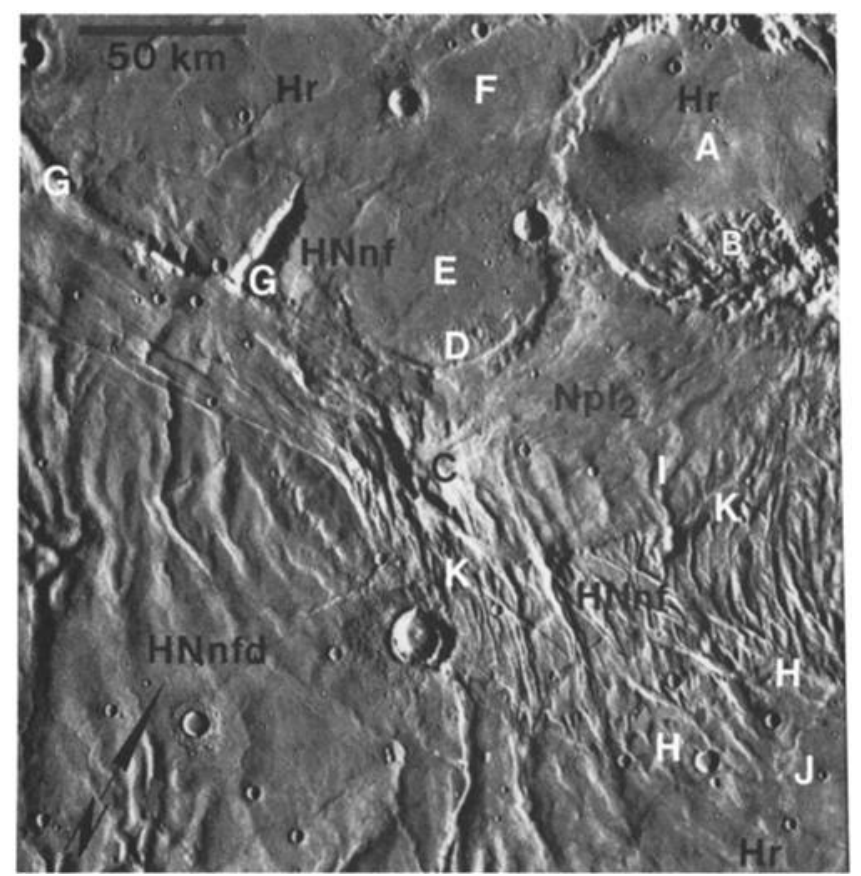

Figure 5. Part of southern Coprates rise. See Figure 2a for contacts and geologic units. Rim of ancient crater (centered at A) partly buried by mountain (B). This mountain and the one at location $\mathrm{C}$ may be ancient volcanoes. On northwest flank of Coprates rise, dissected crater-fill material (D) has been tilted northwest. Unit is overlain by a series of beds $(E, F)$ in the ridged plains and Nectaris Fossae materials (units $\mathrm{Hr}$ and $\mathrm{HNnf}$ ). Note linear depressions (G) that may be structurally controlled volcanic vents, collapse features, or sapping depressions. On southeast flank of rise, a series of hogbacks $(\mathrm{H})$ indicates a south-tilted sequence of strata in unit HNnf. Small channels (I) originate from intercrater plains material (unit $\mathrm{Npl}_{2}$ ) and dissect the tilted strata. Similar channels dissect chiefly massive material (unit HNnfd) that appears to bury hogbacks of unit HNnf. Ridged plains material (J) laps onto the base of the rise. Long scarp marking edge of unit HNnf may delineate a normal fault. Viking image 610A42. of the Coprates rise. The dissected material generally appears to be without bedding, with the exception of one prominent, tilted bed (Figure 5). The dissected material possibly forms a mantle largely made up of pyroclastic rocks; some channels originate from a riftlike structure (Figure 5) and thus may have formed by pyroclastic flows. Alternatively, local volcanism and tectonism may have caused the release of groundwater in this area, resulting in sapping of poorly indurated rocks.

During the Early Hesperian, low areas east and southeast of the Coprates rise were covered by ridged plains material (unit $\mathrm{Hr}$ ), which is marked by generally north-trending wrinkle ridges

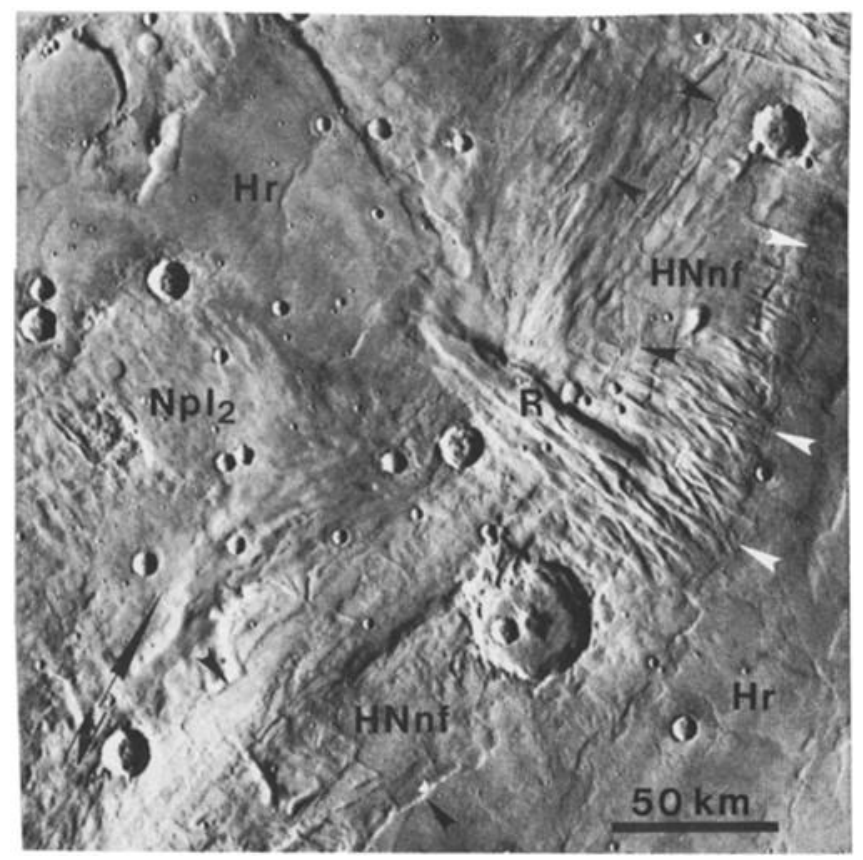

Figure 6. Part of northern Coprates rise. Rise covered by faulted material of Nectaris Fossae (unit HNnf), which embays intercrater plains material (unit $\mathrm{Npl}_{2}$ ) on west flank of rise. Both sides of rise embayed by ridged plains material (unit $\mathrm{Hr}$ ); along its east flank, edge of ridged plains material locally appears to consist of upturned beds (white arrows). East-trending faults in unit HNnf concentrated along riftlike structure ( $R$ ). Many northtrending structural depressions appear to be filled by lobate flows (black arrows). Viking image 610A25. 
of compressional origin. Along the south edge of the map area, relatively smooth and moderately cratered plateau material (unit $\mathrm{Hpl}_{3}$ ) was deposited. A northwest-trending, narrow graben system cuts this unit. A mantle (unit $\mathrm{Hm}$ ), whose edges appear eroded, was emplaced on top of plateau and ridged plains materials along the eastern and southern margins of the Coprates rise and on the edge of intercrater plains material farther east. The mantle may be composed of sedimentary deposits resulting from fluvial dissection of adjacent, high-standing Noachian materials or pyroclastics from vents in Nectaris Fossae.

\section{Deformational History of the Coprates Rise and Related Structures}

The east flank of the Coprates rise is steeper than the west flank (Figure 3 ) and its section of tilted beds is thicker, indicating that the folding of these rocks was asymmetric. Perhaps contemporaneously, north-trending arches and swales parallel to the rise formed elsewhere on the Thaumasia plateau (Figure 2a). The layered sequence (unit HNnf) was also intensely fractured in places, forming Nectaris Fossae. These fractures are normal faults, grabens, and small rift-like structures that mainly trend west, although a few trend northwest. They are mostly limited to the rise and do not cut ridged plains material.

Later, during the early part of the Hesperian, east-west compression produced north-trending wrinkle ridges, mostly in ridged plains material (unit $\mathrm{Hr}$ ). Arching of the Coprates rise may have continued, uplifting and folding what may be lower beds of ridged plains material (Figure 6). Younger structures near the rise include wrinkle ridges and strike-slip faults [Schultz, 1989; Watters, 1992] to the east and pit-crater chains and grabens of eastern Valles Marineris to the north [Tanaka and Golombek, 1989; Schultz, 1991]. The rise does not continue north of Coprates Chasma.

\section{Causes of Uplift}

Our investigation thus far has established that the Coprates rise was formed by $2-4 \mathrm{~km}$ of uplift of Upper Noachian through Lower Hesperian material. Anticlinal folding of these units is indicated by the tilting of Noachian and perhaps Hesperian layers along both western and eastern margins of the rise. Topographic data and the morphology and tilting of layers show that the Coprates rise and the adjacent swale to the east define an asymmetric anticline-syncline pair trending approximately north to northeast, with the steeper limb on the east side of the rise.

Uplift of crustal layers can be caused by a variety of processes, including unstable horizontal compression (producing either a buckling instability [e.g., Zuber and Aist, 1990; Martinod and Davy, 1992] or thrust faulting [e.g., Johnson, 1980]), extension, lateral deformation (associated with strike-slip faults), or vertical displacement [e.g., Haneberg, 1992]. Some of these processes are depicted in Figure 7. Strike-slip faulting as the principal mechanism can be ruled out based on the apparent lack of horizontal offsets along structures associated with the rise. Vertical displacement of the crust beneath the Coprates rise (e.g., laccolith emplacement) is unlikely given the scale and the asymmetry of the deformation. An origin by localized crustal extension and normal faulting was suggested by Plescia et al. [1980] and Craddock et al. [1990]. Thrust faulting
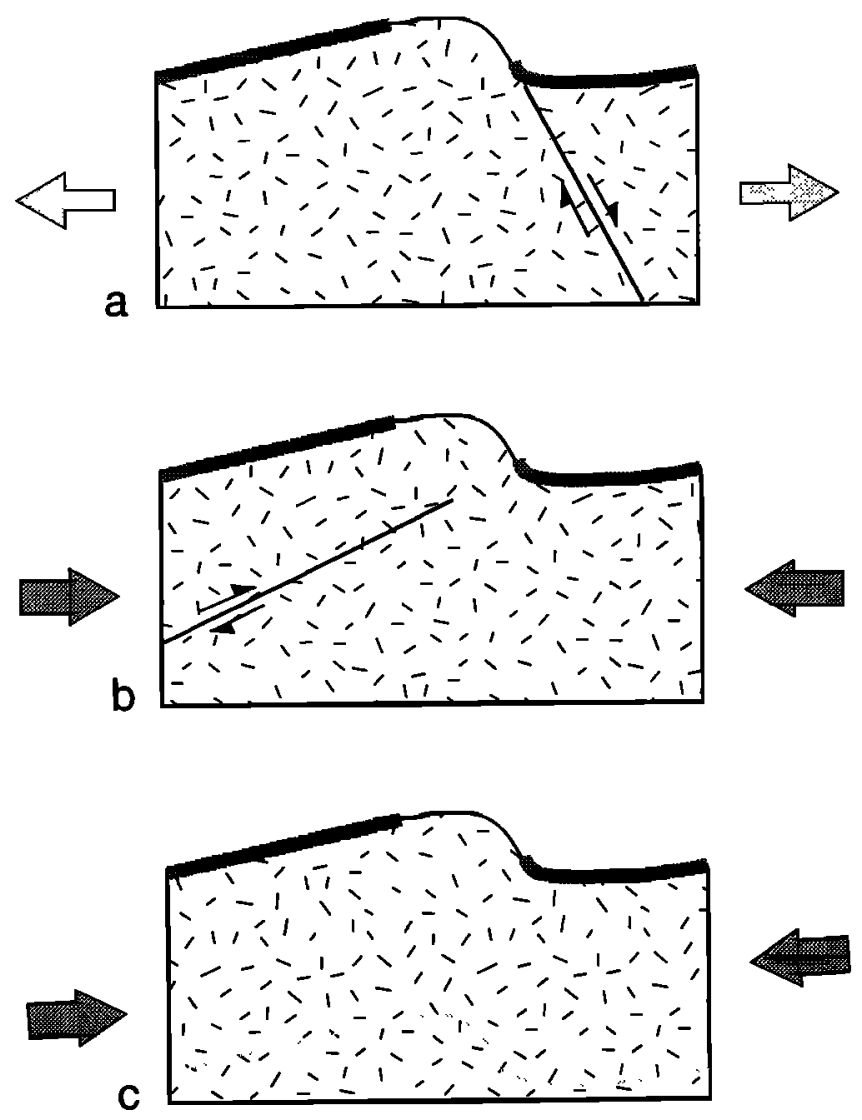

Figure 7. Schematic diagrams of processes suggested to have produced near-surface uplift and folding at Coprates rise: (a) normal faulting, (b) thrust faulting, (c) buckling.

might be anticipated given the broad east-west extent of the uplift and the archlike morphology of the rise [e.g., King et al., 1988].

We use a dislocation approach to model the surface topography and to discriminate between fundamental alternatives for related or suggested subsurface structure. In this approach, displacements of the surface due to slip on a subjacent fault are calculated for a range of plausible fault geometries, as discussed below. Our intent is to evaluate certain first-order scenarios, such as normal versus thrust faulting, that might be related to large-scale arch topography. Although the dislocation methods used in this analysis work for cases in which the subsurface structure is either well known or can be constrained (e.g., focal mechanisms or drilling), inversion of surface topography for subsurface structure in the absence of such data can be a difficult exercise. For example, the detailed topographic expression of an arch may result from slip along several near-surface faults, making inversions inherently nonunique. Further, uncertainties in Martian topography imply ambiguities in the details of fault dip, length, and other factors. Improved topography, such as that available for the Moon [e.g., Golombek et al., 1991] or from a Mars Observer [Zuber et al., 1992] class spacecraft, could be used to better constrain future fault inversions. However, many of the major, first-order characteristics of subsurface structure associated with ridge topography can be determined by using a dislocation analysis and the presently available data. Thus we can test whether 
normal or thrust faults are consistent with ridge topography, which had not been done previously, and we can identify plausible ranges of fault dimensions.

The possible contributions of normal or thrust faulting to uplift of the Coprates rise can be evaluated quantitatively by calculating surface displacements due to slip along a buried fault in an elastic half-space (see review by $L i$ [1987]). This wellknown method [e.g., Mansinha and Smylie, 1971; Freund and Barnett, 1976] involves specifying the fault geometry and slip and adjusting these parameters until the calculated surface displacements approximate the observed topography. The associated surface displacements $u_{x}$ and $u_{y}$ due to slip along the fault are calculated using the expressions

$$
\begin{aligned}
& u_{x}= U_{v} \frac{\sin \delta}{\pi}\left[\frac{s_{1}\left(s_{1}-x \cos \delta\right)}{x^{2}+s_{1}{ }^{2}-2 s_{1} x \cos \delta}\right] \\
&-\frac{s_{2}\left(s_{2}-x \cos \delta\right)}{x^{2}+s_{2}{ }^{2}-2 s_{2} x \cos \delta} \\
&+\cos \delta \tan ^{-1}\left(\frac{x-s_{1} \cos \delta}{d_{1}}\right)-\tan ^{-1}\left(\frac{x-s_{2} \cos \delta}{d_{2}}\right) \\
& u_{y}= U_{v} x(\sin \delta)^{2}\left(\frac{s_{1}}{x^{2}+s_{1}{ }^{2}-2 s_{1} x \cos \delta}\right) \\
&-\frac{s_{2}}{x^{2}+s_{2}{ }^{2}-2 s_{2} x \cos \delta} \\
&+\sin \delta \tan ^{-1}\left(\frac{x-s_{1} \cos \delta}{d_{1}}\right)-\tan ^{-1}\left(\frac{x-s_{2} \cos \delta}{d_{2}}\right) \\
& u_{x y}=\sqrt{\left(u_{x}\right)^{2}+\left(u_{y}\right)^{2}}
\end{aligned}
$$

in which $U_{\nu}$ is the dip-slip displacement along the fault having dip angle $\delta$ and depth parameters $d_{1}$ and $d_{2}$ as defined in Figure $8, s_{1}=d_{1} / \sin \delta$, and $s_{2}=d_{2} / \sin \delta$.

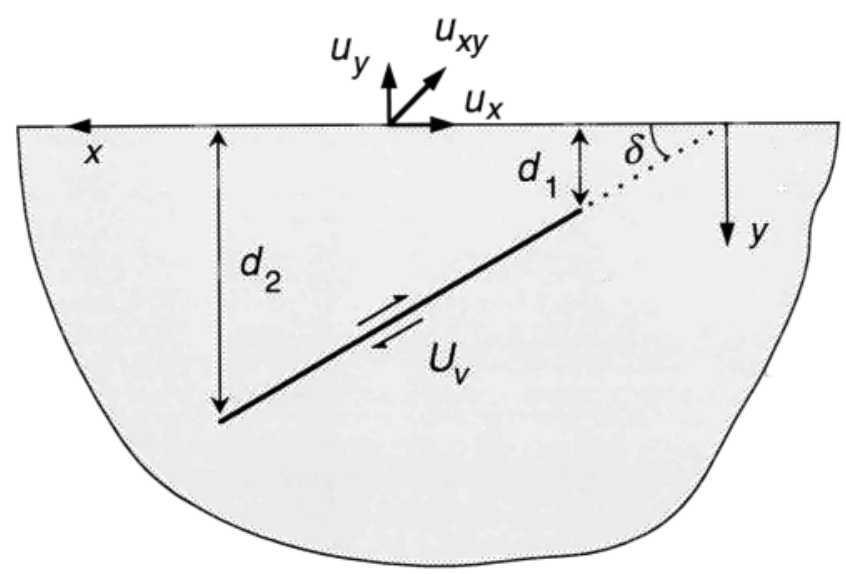

Figure 8. Geometry of dislocation problem showing parameters used in calculation of surface deformation $u_{x y}$ due to slip along a fault. Both normal and thrust faults can be considered by choosing appropriate values of fault dip and sense of displacement along the fault. Parameters are defined in text.

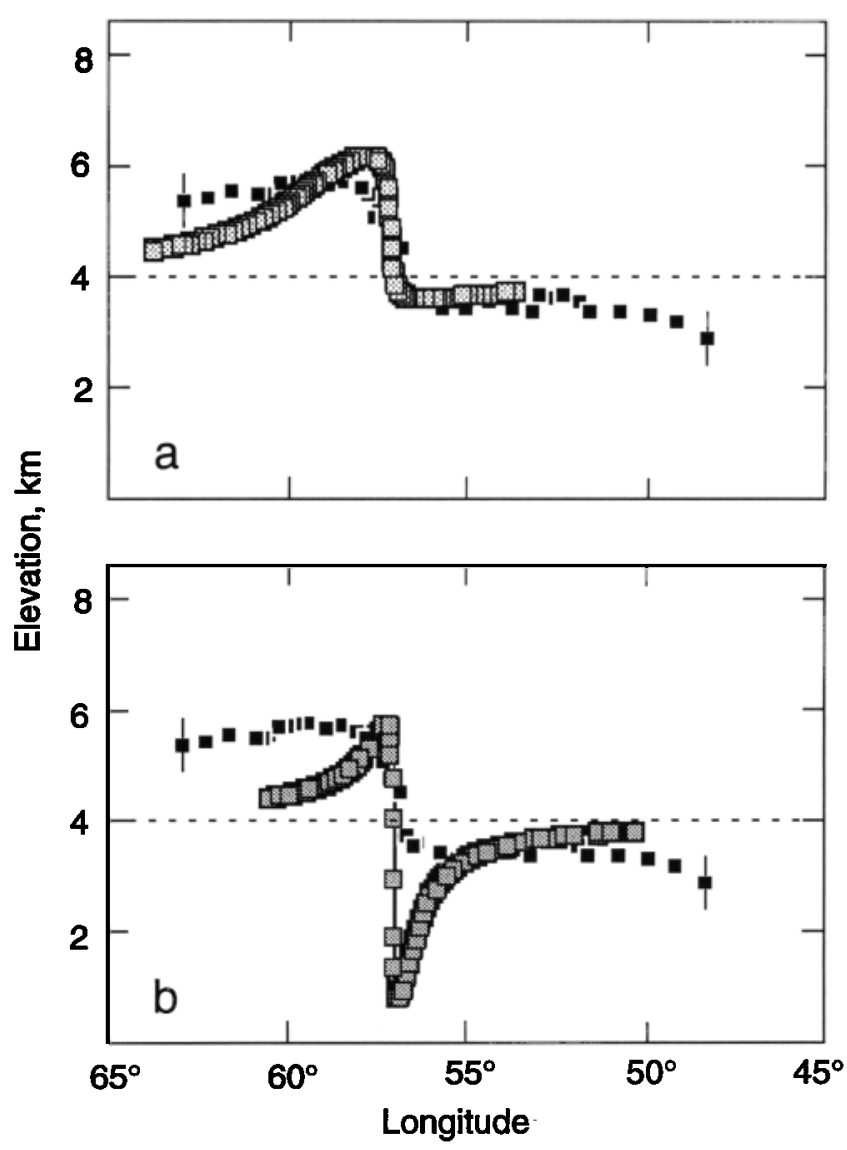

Figure 9. Comparison between radar topography (solid black squares) across Coprates rise for $19^{\circ} \mathrm{S}$ and calculated surface displacements $u_{x y}$ (shaded squares) due to slip along buried faults using best fitting parameters. Error bars at endpoints show \pm 200 - $m$ uncertainty in elevation measurements; profile modified to compensate for superposed volcano (unit Nm in Figure 2a) and for erosion on east flank of rise. Reference line (dashed) at 4-km elevation shows hypothetical planetary surface before fault displacement. (a) Buried thrust fault; (b) buried normal fault.

Representative results of the calculations for thrust and normal faults are given in Figure 9. The best fitting parameters for the thrust fault case (Figure 9a) are $d_{1}=5 \mathrm{~km}$ (a "blind" or buried thrust fault), $d_{2}=105 \mathrm{~km}$, slip $-U_{v}=1 \mathrm{~km}$ (reverse), and dip angle $30^{\circ}$ to the west. In the best fit to the topography using a normal fault solution (Figure 9b), we assume a buried fault with $d_{1}=2 \mathrm{~km}, d_{2}=50 \mathrm{~km}$, slip $U_{v}=2 \mathrm{~km}$ (normal), and dip angle $60^{\circ}$ to the east. In both cases the shallower fault tip directly underlies the inflection point in the topographic profiles at long $57^{\circ}\left(d_{1}\right.$ in Figure 8). Although details of the surfacedisplacement profile for thrust or normal fault cases depend on specific values of fault dip, slip, and depth, values of these parameters that we investigated other than those given above provide a poorer fit to the topography than the ones given in Figure 8. For example, the slope of the displacement profile adjacent to the inflection between uplift and subsidence is too steep to adequately match the topography for faults shallower than those used in the figure (e.g., for surface-breaking thrust or normal faults for which $d_{1}=0$ ).

The comparison between calculated and observed 
topographies of the rise depends in part on how well the observed topography represents the actual fold form. The radar data have a horizontal resolution of $1.3^{\circ}$ in latitude and $0.16^{\circ}-$ $0.8^{\circ}$ in longitude and a vertical precision of about $200 \mathrm{~m}$ [Roth $\mathrm{et}$ al., 1980; Downs et al., 1982]. Modifications of the radar profile that are justified to better represent the fold topography include removal of the 1-km-high peak on the west side of the rise crest attributed to a volcano (unit $\mathrm{Nm}$ in Figure 2a) and addition of topography to the east flank to partly account for the erosion that probably has worn down the upper part of the steeper flank of the rise. Even when the modified topography is compared with the fault solutions, however, it is clear that the topography of the Coprates rise cannot be derived by an east- or west-dipping normal fault, as has been previously suggested.

A thrust-fault solution, on the other hand, can be formulated that approximately follows the topography. However, the best fitting case requires a hypothetical thrust fault that extends $>100$ $\mathrm{km}$ deep and $\sim 175 \mathrm{~km}$ to the west. By implication, the thrustfault origin requires an elastic lithosphere more than $100 \mathrm{~km}$ thick in southern Tharsis during Noachian time and "domino style" shortening along faults spaced 75-250 km apart (assuming $30^{\circ}$ dip and map-view spacing of $150-500 \mathrm{~km}$ ). Significant rotations of the fault-bounded blocks due to fault slip might be expected [Mandl, 1987], although such tilting is not yet recognized in the topographic profiles. In addition, changes in arch asymmetry around the margin of the Thaumasia plateau imply that subjacent thrust faults might intersect and impede one another at depth. While we acknowledge the possibility that thrust faulting may have contributed to arch formation (as illustrated in several examples below), we do not necessarily consider it the primary or sole mechanism for arch uplift or spacing.

The elastic half-space solution noted above neglects some potentially important effects. Most importantly, it assumes that the elastic lithosphere is indefinitely thick and that no significant stress relaxation during the postseismic period occurs beneath the seismogenic depth. Such relaxation can be important in reducing the effective elastic thickness of continental crust in faulted regions [King et al., 1988; King and Ellis, 1990] and in rotating and broadening the near-surface topographic signature of fault-related deformation [see King et al., 1988]. A robust indicator of the amount of relaxation may be the relative asymmetry between displacements across a fault [King et al., 1988, Figure 11]. For coseismic surface deformation above a thrust fault, the magnitude of uplift over the fault plane greatly exceeds the magnitude of subsidence in the basin formed ahead of the thrust. In contrast, complete relaxation of coseismic stress beneath the faulted layer promotes more equal displacements by reducing the uplift and deepening the basin. These effects can be amplified by erosion of the upper plate and deposition into the basin [Stein et al., 1988]; the opposite sense of change is caused by relaxation of crust containing normal faults.

On Mars, many clear examples of both normal faults and thrust faults (lobate scarps) exist that have not been eroded significantly. Interestingly, the magnitude of uplift in the upper plates of large thrust faults such as Amenthes Rupes [Watters, 1993], for example, is consistently greater than the magnitude of subsidence across the fault. A comparable case can be made for the Coprates rise and for large normal faults in Valles Marineris, which locally accommodate $\sim 10 \mathrm{~km}$ of subsidence and only $1-2$ km of corresponding uplift [e.g., Schultz, 1991]. We infer from the above arguments that the Martian crust or lithosphere beneath many large thrust and normal faults did not experience significant postseismic deformation due to stress relaxation at shallow depth. Thus the local effective elastic thickness on Mars at the time of Coprates rise uplift apparently was sufficiently great that this process may not have been important.

Finally, we consider buckling and folding due to horizontal compression as mechanisms that can explain uplift of the Coprates rise. Evidence in the form of hogbacks for tilting of beds on the flanks of the rise was presented above, and the crosssectional form of the rise and trough to the east are indicative of broad-scale folding. Although the apparent lack of surfacebreaking thrust faults or lobate scarp morphology could indicate folding due to either a blind thrust fault or buckling instability, the quasi-periodic spacing of the Coprates rise and associated ridges can be attributed more directly to folding than to a series of thrust faults. Folding can occur earlier during layer-parallel compression than can faulting [e.g., Zuber and Aist, 1990; Watters, 1991] if sufficient stratification or strength contrast between layers exists [Johnson, 1980]. Thrust faults that may be associated with ridge structure can nucleate and grow in the cores of the anticlines. Buckling and folding of the Coprates rise structures may indicate that mechanisms for increasing strength contrasts, such as elevated pore-water pressure, were significant during Noachian through Hesperian time in the south Tharsis region.

Fold geometry has not been examined quantitatively here, but it can be compared qualitatively with the characteristics of known terrestrial folds of similar scale [e.g., Watters, 1987] (given differences in surface gravities). On Earth, one possible analogy is a series of folds and high-angle reverse faults that deforms the Indo-Australian plate, probably as a result of convergence between India and Asia [Weissel et al., 1980; Cloetingh and Wortel, 1986; Wiens et al., 1986]. These folds have a wavelength of $100-300 \mathrm{~km}$ and relief of $1-3 \mathrm{~km}$. The anticlines and associated thrust faults [e.g., Petroy and Wiens, 1989] appear to accommodate shortening of the plate-margin region due to unstable horizontal compression and resulting buckling instability of the Indo-Australian plate [e.g., Zuber, 1987a]. However, these terrestrial folds are very complex in detail, perhaps involving reactivation of steep normal faults as thrusts in association with the ridges (Bull and Scrutton [1992]; M.T. Zuber, personal communication, 1993). On the basis of these complexities, we infer that the Coprates rise and associated ridges in Thaumasia probably have components of both buckling and thrust faulting whose relative importance varied from place to place within the belt.

\section{Implications for Regional and Global Tectonics}

\section{The South Tharsis Ridge Belt}

The south Tharsis region includes Daedalia Planum (made up of relatively young lava flows primarily from Arsia Mons) and the Thaumasia plateau (Figure 1), a large Noachian to Lower Hesperian [Tanaka, 1986] volcanotectonic province. The margin of the Thaumasia plateau is irregular to arcuate in plan view. The Thaumasia province is characterized by normal faults and grabens [McGill, 1978], many of which are subradial to Solis Planum [Frey, 1979; Masson, 1980; Plescia and Saunders, 
1982], and by wrinkle ridges and arches discussed in this paper. Lobate scarps that may indicate surface-breaking thrust faults also define part of the southern margin of the plateau [Plescia and Saunders, 1982].

Given the complexity of deformation in Thaumasia, including suggestions of thrust faulting [e.g., Plescia and Saunders, 1982], we searched for other possible large-scale ridge and scarp structures (typically larger than those associated with wrinkle ridges) in the south Tharsis region [e.g., Watters, 1993]. To confirm a contractional origin for these landforms, we looked for specific morphologic characteristics suggestive of compression, such as (1) broad, high ridges (as defined morphologically or by radar altimetry); (2) crested ridges (straight to sinuous and typically higher than wrinkle ridges); (3) high, sinuous or lobate scarps (also higher than wrinkle ridges); (4) wrinkle ridges on adjacent plains material that parallel or join crested ridges or sinuous scarps; (5) truncated or shortened impact-crater rims along sinuous scarps or crested ridges; and (6) tilted rock layers (hogbacks). However, we did not consider preferential or relative orientation, such as concentricity to Thaumasia or some other area, as indicative of, or evidence for, contractional deformation.
In Figure 1 we indicate the location of 29 large ridges and scarps of possible contractional origin that, interestingly, are generally concentric to south Tharsis. We group these structures in the "south Tharsis ridge belt"; the aforementioned morphologic characteristics associated with each structure are given in Table 2. Most of the ridges deform Lower to Upper Noachian plateau materials and are embayed by Lower Hesperian smooth, ridged, and fractured plains materials [see Scott and Tanaka, 1986]. Therefore, most of the ridge belt is probably Noachian in age, although minor Early Hesperian deformation can be seen to postdate emplacement of smooth, intercrater plains material in many places. Although many contractional structures have been noted by others, an early (Noachian) regional-scale system of such structures heretofore has not been recognized.

The ridge belt comprises subgroups that differ in morphology according to location and deformational style. The numbers are those of ridge numbers in Figure 1 and Table 2. The first subgroup consists of ridges 1-10 associated with Memnonia Fossae. Ridges are generally high, broad (tens of kilometers across), and bordered and crossed by crested ridges (mostly 5 to $10 \mathrm{~km}$ wide) and high sinuous scarps. Several

Table 2. South Tharsis Ridge Belt Structures

\begin{tabular}{|c|c|c|c|c|c|c|c|c|c|}
\hline Ridge* & $\begin{array}{l}\text { Lat, } \\
\text { deg }\end{array}$ & $\begin{array}{c}\text { Long, } \\
\text { deg }\end{array}$ & $\begin{array}{c}\text { Length, } \\
\text { km }\end{array}$ & $\begin{array}{l}\text { Broad } \\
\text { Ridges }\end{array}$ & $\begin{array}{l}\text { Crested } \\
\text { Ridges }\end{array}$ & $\begin{array}{c}\text { Sinuous } \\
\text { Scarps }\end{array}$ & $\begin{array}{l}\text { Wrinkle } \\
\text { Ridges }\end{array}$ & $\begin{array}{c}\text { Deformed } \\
\text { Craters }\end{array}$ & Hogbacks \\
\hline 1 & -7 & 149 & 120 & $\mathbf{X}$ & & $\mathbf{X}$ & & $\mathrm{X}$ & \\
\hline 2 & -6 & 142 & 200 & $\mathbf{X}$ & $\mathbf{X}$ & $X$ & & & \\
\hline 3 & -10 & 147 & 150 & $\mathbf{X}$ & & $\mathbf{X}$ & & $\mathbf{X}$ & \\
\hline 4 & -16 & 148 & 400 & $\mathbf{X}$ & $\mathbf{X}$ & $\mathbf{X}$ & & $\mathrm{X}$ & $\mathbf{X}$ \\
\hline 5 & -25 & 152 & 600 & $\mathbf{X}$ & $\mathbf{X}$ & $\mathbf{X}$ & $\mathbf{X}$ & $\mathbf{X}$ & \\
\hline 6 & -21 & 147 & 250 & $\mathbf{X}$ & & $\mathbf{X}$ & & & \\
\hline 7 & -23 & 145 & 250 & $\mathbf{X}$ & $\mathbf{X}$ & $\mathbf{X}$ & & & $\mathbf{X}$ \\
\hline 8 & -29 & 144 & 350 & $\mathbf{X}$ & $\mathbf{X}$ & $\mathbf{X}$ & & & \\
\hline 9 & -23 & 142 & 150 & $\mathbf{X}$ & $\mathbf{X}$ & $\mathbf{X}$ & & & \\
\hline 10 & -26 & 139 & 400 & & $\mathbf{X}$ & $\mathbf{X}$ & & & \\
\hline 11 & -38 & 138 & 350 & & & $\mathbf{X}$ & $\mathbf{x}$ & $\mathbf{X}$ & \\
\hline 12 & -35 & 136 & 300 & & $\mathbf{X}$ & $\mathbf{X}$ & & & $?$ \\
\hline 13 & -37 & 130 & 250 & $\mathbf{X}$ & $\mathbf{X}$ & $\mathbf{X}$ & & & \\
\hline 14 & -37 & 125 & 250 & & $\mathbf{X}$ & $\mathbf{x}$ & & & \\
\hline 15 & -43 & 124 & 200 & $\mathbf{X}$ & $\mathbf{X}$ & $\mathbf{X}$ & & & \\
\hline 16 & -42 & 120 & 400 & & $\mathbf{X}$ & $\mathbf{X}$ & $\mathbf{X}$ & $\mathbf{X}$ & \\
\hline 17 & -38 & 113 & 120 & & $\mathbf{X}$ & $\mathbf{X}$ & & & \\
\hline 18 & -29 & 110 & 200 & & & $\mathbf{X}$ & & & \\
\hline 19 & -33 & 110 & 150 & & $\mathbf{X}$ & $\mathbf{X}$ & & & \\
\hline 20 & -37 & 109 & 350 & $\mathbf{X}$ & $\mathbf{X}$ & $\mathbf{X}$ & & & \\
\hline 21 & -41 & 97 & 250 & & $\mathbf{X}$ & $\mathbf{X}$ & & & \\
\hline 22 & -44 & 92 & 500 & $\mathbf{X}$ & $\mathbf{X}$ & $\mathbf{X}$ & $\mathbf{X}$ & $\mathbf{X}$ & \\
\hline 23 & -40 & 82 & 750 & $\mathbf{X}$ & & & & & $\mathbf{X}$ \\
\hline 24 & -30 & 79 & 300 & & $\mathbf{X}$ & & $\mathbf{X}$ & & \\
\hline 25 & -25 & 73 & 250 & & $\mathbf{X}$ & & & & $\mathbf{X}$ \\
\hline 26 & -18 & 66 & 300 & $\mathbf{X}$ & & & & & \\
\hline 27 & -28 & 59 & 1200 & $\mathbf{X}$ & $\mathbf{X}$ & & $\mathbf{X}$ & & $\mathbf{X}$ \\
\hline 28 & -20 & 51 & 450 & $\mathbf{X}$ & & & & & \\
\hline 29 & -34 & 55 & 300 & $\mathbf{X}$ & & $\mathbf{X}$ & & $\mathbf{X}$ & \\
\hline
\end{tabular}

* See Figure 1 . 


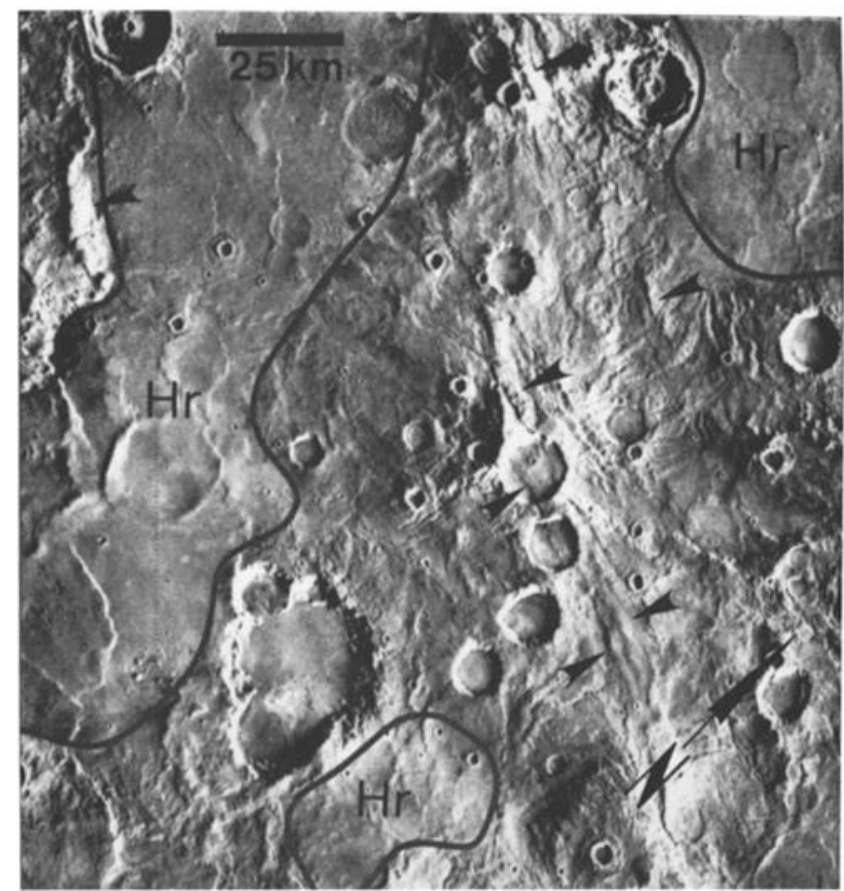

Figure 10. Aligned crested ridges and sinuous scarps (arrows) in Terra Sirenum (ridge 14 in Figure 1 and Table 2) embayed by patches of ridged plains material (unit $\mathrm{Hr}$, outlined areas). Viking image $56 \mathrm{~A} 35$ centered at lat $37^{\circ} \mathrm{S}$, long $124^{\circ}$.

shortened craters occur along the scarps. These ridges probably formed mainly by thrust faulting; however, two broad ridges (4 and 7) display possible hogbacks and warped surfaces indicative of folding. Crested ridges, here and elsewhere, may result from localized buckling along the toes of overthrust plates.

The second subgroup consists of ridges 11-17 in Terra Sirenum. They are relatively modest topographic highs mainly

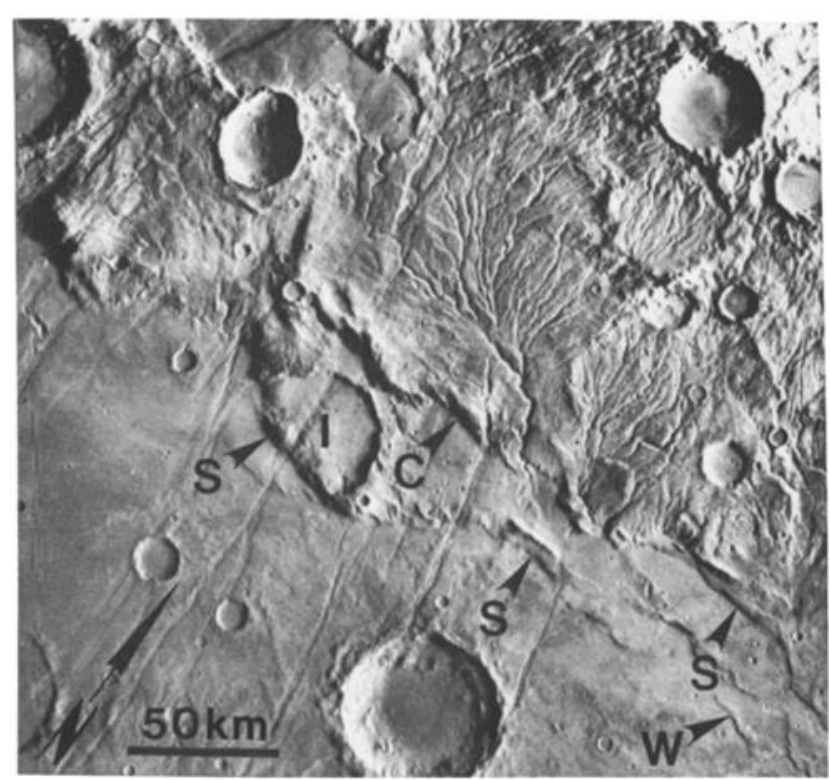

Figure 11. Crested ridges (C), sinuous scarps (S), and wrinkle ridges (W) aligned with part of southwest margin of Thaumasia plateau (ridge 22 in Figure 1 and Table 2). Note missing part of rim of impact crater at I. Part of Viking image 606A56 centered at lat $44^{\circ} \mathrm{S}$, long $94^{\circ}$.

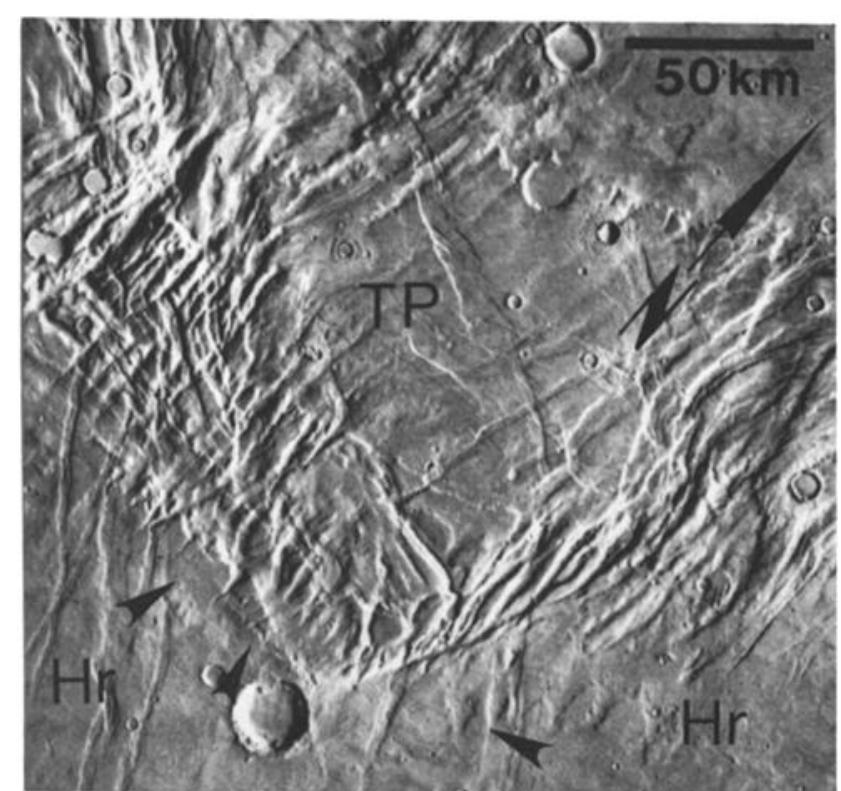

Figure 12. Part of southeast margin of Thaumasia plateau (TP; ridge 23 in Figure 1 and Table 2). Upturned strata that form hogbacks (arrows) indicate asymmetric folding. Hogbacks (similar to those on Coprates rise) are embayed by younger, less fractured ridged plains material (Hr). Part of Viking image 606A52; centered at lat $41^{\circ} \mathrm{S}$, long $84^{\circ}$.

characterized by crested ridges and sinuous scarps, and thus they likely formed by thrust faults of moderate displacement (see Figure 10).

The third subgroup, ridges 18-22, occurs along the southwestern margin of the Thaumasia plateau. The ridges are similar to structures of Terra Sirenum, but locally have greater relief. They locally define the plateau margin (see Figure 11). The landforms probably formed mainly by thrust faulting directed radially outward from the Thaumasia plateau. Degraded-appearing ridges concentric to the plateau margin but within the plateau (not shown in Figure 2) may also be contractional structures.

The fourth subgroup consists of ridges 23-29 in the eastern Thaumasia plateau region. The structures are long, broad, lowto high-relief rises consisting of broad ridges (Figure 12) or groups of parallel crested ridges (Figure 13). Ridges shown in Figure 13 appear strikingly similar to ridges that either deform plains units or border many tesserae on Venus [e.g., Squyres et al., 1992; Bindschadler et al., 1992]. The Coprates rise and another ridge (number 23) developed along the southeastern margin of the plateau have developed hogbacks (Figures 5 and 12). The other ridge structures are broad yet have low to moderate relief; two (numbers 26 and 28) are distinguished primarily by their topographic expression provided by radar altimetry (Figure 3 ).

\section{Shallow and Deep Lithospheric Structure}

The association of the Coprates rise with a set of other ridges of varied structural expression carries interesting implications for the scales and styles of contractional deformation along the margin of south Tharsis. Overall, the ridges are typically separated by some $150-500 \mathrm{~km}$ and have relief of hundreds of 


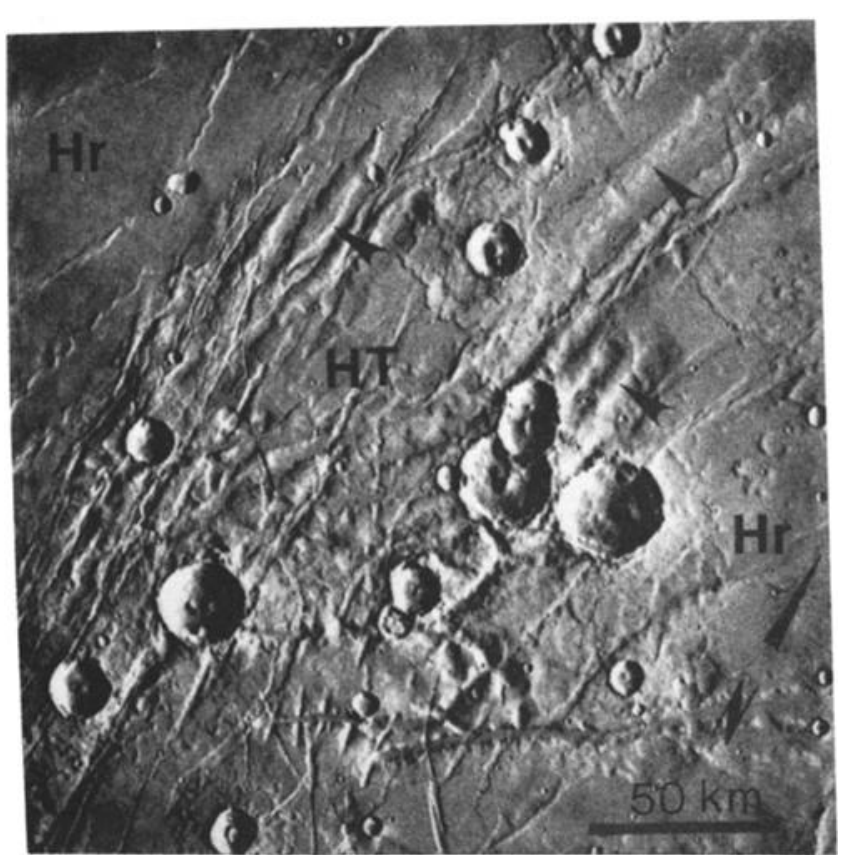

Figure 13. Rugged, heavily cratered highland terrain (HT) forming broad high area along east edge of Solis Planum (ridge 25 in Figure 1 and Table 2); highlands embayed by ridged plains material (Hr). Low, degraded crested ridges (arrows) may be ancient contractional structures. Note similarity between these ridges and those bordering certain tesserae on Venus. Part of Viking image $608 \mathrm{~A} 28$ centered at lat $23^{\circ} \mathrm{S}$, long $72^{\circ}$.

meters to as much as $2 \mathrm{~km}$. Given their geomorphologic characteristics, their common spacing and trends, their general temporal association with the Coprates rise, and their spatial association with wrinkle ridges, we suggest that the south Tharsis ridge belt formed by a combination of buckling instability and thrust faulting. The large horizontal scale (150$500 \mathrm{~km}$ ) of periodic folding and thrusting represented by the ridges implies unstable horizontal compression of perhaps the entire Martian lithosphere, rather than deformation of only the crust or other thin, near-surface layers. The possibility of buckling of the Martian lithosphere was suggested previously for the three ridges resolved by radar measurements just south of eastern Valles Marineris (in upper part of Figure 2a) by Watters [1987]; our investigation extends the hypothesis of lithospherescale, periodically spaced ridge development to the entire outer margin of the south Tharsis region. The range in spacing (150$500 \mathrm{~km}$ ) among the ridges that we have mapped is within the range of plausible dominant wavelengths $(100-1000 \mathrm{~km})$ of whole-lithosphere folding for Mars suggested by Zuber and Aist [1990].

Horizontal shortening of the lithosphere produced by compression should have resulted in some thickening of the lithosphere; this thickening may have led to increases in the average elevation of shortened regions. The Thaumasia plateau is the largest and highest region of exposed Noachian rocks on Mars, with elevations ranging from about 5 to $9 \mathrm{~km}$. This plateau is isostatically compensated. Additionally, the inferred structures in Terra Sirenum and northwest of Argyre are located in much of the remaining areas of Noachian rocks higher than 6 $\mathrm{km}$ [U.S. Geological Survey, 1989]. It is reasonable to speculate at this point that higher average elevations and apparently thicker lithosphere in the south Tharsis region may be related to lithospheric contraction, buckling, and thrust faulting as manifested in the south Tharsis ridge belt. On the other hand, preliminary work by Zuber and Parmentier [1993] suggests an association of plateau-margin mountain belts with thinner lithosphere beneath the plateau; these circumferential mountain belts would also have been formed through regional compression.

Lithospheric structure adjacent to the ridge belt. Gaps in the ridge belt mostly occur in areas where Hesperian and Amazonian plains materials bury the central part of the Thaumasia plateau, in low areas south and west of the plateau, and in Daedalia Planum [Scott and Tanaka, 1986]. In these areas, ridges either did not develop or were buried (Figure 1). Also, the ridges are not observed to continue into the remainder of the Tharsis region north of Memnonia Fossae, Tharsis Montes, and Noctis Labyrinthus-Valles Marineris. In particular, the Coprates rise appears to die out northward along strike, and it may end in or near the easternmost set of large pit-crater chains adjacent to Coprates Chasma near lat $16^{\circ} \mathrm{S}$, long $57^{\circ}$. On the other hand, ridges are particularly well developed and closely spaced in the Memnonia region [Schultz, 1985] in spite of their relatively great distance from the Thaumasia plateau. These ridges are heavily cratered and may in part be influenced by previous structure such as ring faults of a large impact basin [e.g., Craddock et al., 1990].

Troughs in the Valles Marineris system are thought to have formed principally during Early to Late Hesperian time, because they transect plains materials and wrinkle ridges of Hesperian age [Scott and Tanaka, 1986; Tanaka, 1986; Schultz, 1991; Lucchitta et al., 1992]. Thus they are likely younger than the Coprates rise (which is probably Upper Noachian to perhaps Lower Hesperian), and the Valles Marineris troughs as presently defined appear to have formed near the northern margin of the previously deformed Thaumasia plateau.

The apparent lack of continuation or development of the Coprates rise and adjacent topography north of Valles Marineris suggests to us that crustal and/or lithospheric properties such as layering or stress states beneath Lunae Planum and the Thaumasia plateau differed significantly while rise and ridge belt were being deformed. We infer that Valles Marineris and the high areas extending toward the troughs from Syria Planum [U.S. Geological Survey, 1989; Lucchitta et al., 1994] may also have been localized by a transition in crustal or lithospheric properties [e.g., Dunbar and Sawyer, 1989] or in stress state between Lunae Planum and the Thaumasia plateau.

Association with wrinkle ridges. Horizontal shortening of crustal or near-surface layers throughout south Tharsis as shown by wrinkle ridges is well documented [e.g., Maxwell, 1982; Chicarro et al., 1985; Watters and Maxwell, 1986]. Wrinkleridge development is noticeably greater in the broad swales than on ridges of the south Tharsis belt (where defined by physiography obtained from Viking images or by Earth-based radar altimetry profiles, such as that near lat $20^{\circ} \mathrm{S}$, long $80^{\circ}$ ). The wrinkle ridges also commonly parallel the swales [Schultz and Frey, 1989] (Figure 2), suggesting that some wrinkle ridges may be second-order structures. These observations are similar to those made by Suppe and Connors [1992] for apparent synclines on Venus.

However, not all wrinkle ridges parallel the ridge and scarp 
structures. For example, the trends of wrinkle ridges differ by some $10^{\circ}$ from that of the Coprates rise at lat $19^{\circ} \mathrm{S}$. These differences in development and trend between wrinkle ridges and long-wavelength, positive-relief structures suggest that wrinkle-ridge formation was spatially associated with, but locally distinct from, formation of the underlying longwavelength structures [cf. Zuber, 1993].

Although the quasi-regular spacing of wrinkle ridges in the south Tharsis region can be attributed to a dominant wavelength of folding [e.g., Zuber and Aist, 1990; Watters, 1991], their characteristic spacing, tens of kilometers, is probably too small to be attributed to lithosphere-scale folding. The coexistence of two scales or wavelengths of folding can be interpreted as a result of partial decoupling between shallow and deeper layers, which requires a weak intermediate layer such as megaregolith or lower crust for both scales of instability to develop [Martinod and Davy, 1992]. The two scales of contractional deformation on Mars are analogous to those noted for other planets such as Venus [Zuber, 1987b].

\section{Relationship of South Tharsis Ridge Belt to Tharsis Evolution}

Previous workers have discussed the evolution of Tharsis in terms of tectonic centers defined by radial and/or concentric patterns of structures [e.g., Frey, 1979; Wise et al., 1979; Plescia and Saunders, 1982; Schultz, 1985; Watters and Maxwell, 1986; Tanaka et al., 1991]. The trends of most ridges in the south Tharsis ridge belt qualitatively suggest a broad tectonic center within the heart of south Tharsis at Solis Planum (about lat $20^{\circ}-$ $25^{\circ} \mathrm{S}$, long $90^{\circ}$ ). This center can be defined by the ridges along the eastern margin of the Thaumasia plateau and in the Memnonia region; a center closer to Syria Planum is expressed by the ridges in Terra Sirenum. The center of tectonism at Solis Planum is reasonably consistent with the scenario of Tharsis development set forth by Frey [1979] and Plescia and Saunders [1982], in which the Thaumasia plateau was identified as an early Tharsis tectonic center, based on the great age of the terrain deformed by the associated radial faults and the compensated gravity signature of the plateau. However, Frey's center of faulting, located near lat $30^{\circ} \mathrm{S}$, long $90^{\circ}$, included trend measurements of some wrinkle ridges south of Valles Marineris and resistant erosional landforms in the troughs, as well as the fanning Thaumasia Fossae grabens. These grabens were later interpreted as part of younger Tharsis tectonism by Plescia and Saunders [1982] and Tanaka et al. [1991]. Plescia and Saunders did not attempt to unravel Thaumasia faulting, citing its complexity and relatively poor exposure.

Concentric contractional structures organized about a center in Thaumasia or south Tharsis have not been noted previously. In addition, the sequence of development of various sets of grabens along the southern and eastern parts of the Thaumasia plateau is not well known. We observe that some of the graben sets are located preferentially on broad ridges and probably reflect near-surface extension contemporaneous with ridge uplift. These grabens apparently are genetically distinct from later Tharsis-radial grabens that locally parallel them in eastern Thaumasia.

The north to northeast orientations of the Coprates rise and adjacent ridge-and-swale topography imply a shortening of lithosphere that was oriented east to southeast in this region (Figure 9). This inferred pattern of shortening is broadly

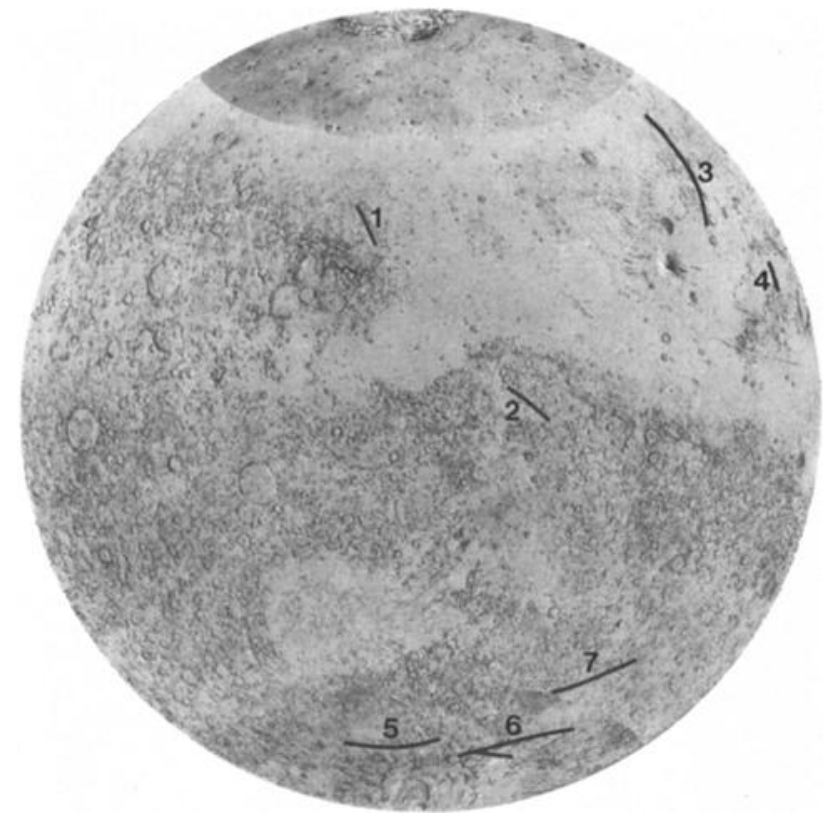

Figure 14a. Large ridge systems on Mars, eastern hemisphere (long $180^{\circ}$ to $360^{\circ}$ ). Unlabeled lines indicate structures of south Tharsis ridge belt (see Figure 1); numbered lines are other ridge systems (described in text and in Table 3 ).

consistent with trajectories of maximum compressive principal stress (calculated for the surface) obtained by Banerdt et al. [1992] for the case of isostatic adjustment of lithosphere due to a Tharsis-centered load. However, the magnitudes of stresses associated with Tharsis models at relevant depths are not available, so it is presently unclear whether isostatic stresses were sufficient to have caused buckling instability or thrust faulting of the lithosphere. A different conceptual scenario for Tharsis tectonics, dubbed the "detached crustal cap model" by Tanaka et al. [1991], envisions radial compression near the

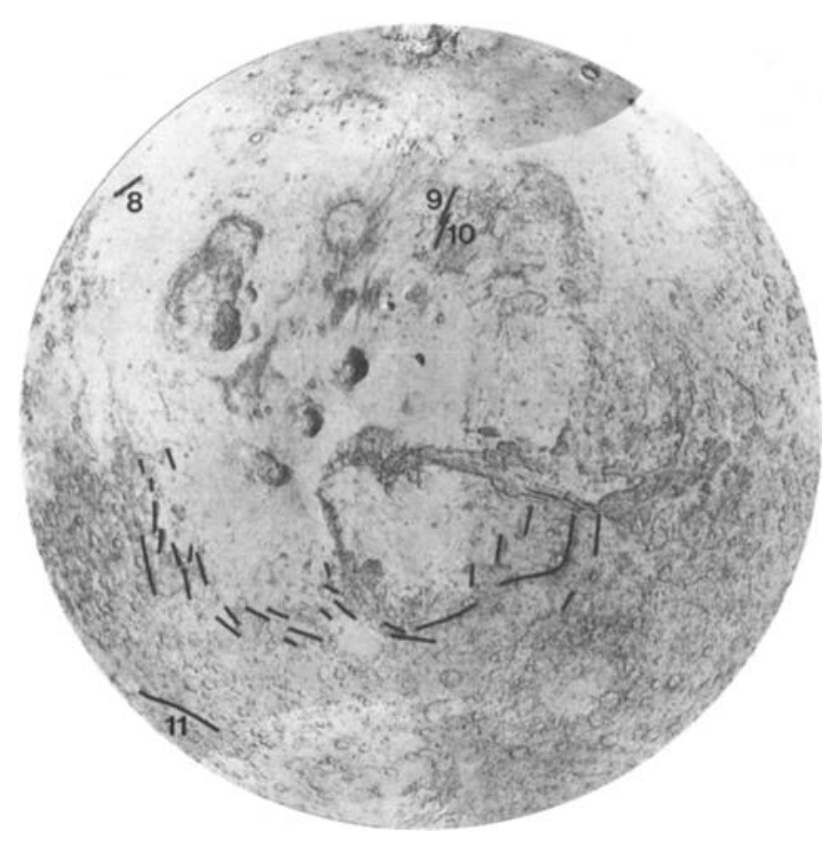

Figure 14b. Same as Figure 14a, but for western hemisphere (long $0^{\circ}$ to $180^{\circ}$ ). 
Table 3. Large Martian Ridge and Scarp Structures (Excluding South Tharsis Ridge Belt)

\begin{tabular}{|c|c|c|c|c|c|c|c|c|c|c|}
\hline Ridge* & $\begin{array}{l}\text { Place } \\
\text { Name }\end{array}$ & $\begin{array}{l}\text { Lat, } \\
\text { deg }\end{array}$ & $\begin{array}{l}\text { Long, } \\
\text { deg }\end{array}$ & $\begin{array}{l}\text { Length, } \\
\text { km }\end{array}$ & $\begin{array}{l}\text { Broad } \\
\text { Ridges }\end{array}$ & $\begin{array}{l}\text { Crested } \\
\text { Ridges }\end{array}$ & $\begin{array}{l}\text { Sinuous } \\
\text { Scarps }\end{array}$ & $\begin{array}{l}\text { Wrinkle } \\
\text { Ridges }\end{array}$ & $\begin{array}{l}\text { Deformed } \\
\text { Craters }\end{array}$ & Hogbacks \\
\hline 1 & Utopia Planitia & 33 & 280 & 500 & & $\mathbf{x}$ & & $\mathbf{X}$ & & \\
\hline 2 & Amenthes Rupes & 2 & 250 & 600 & $\mathbf{X}$ & & $\mathbf{X}$ & & $\mathbf{X}$ & \\
\hline 3 & Phlegra Montes & 40 & 195 & 1400 & $\mathbf{x}$ & & $\mathbf{X}$ & $\mathbf{X}$ & $\mathbf{X}$ & \\
\hline 4 & Arcadia Planitia & 20 & 187 & 250 & $\mathrm{X}$ & $\mathbf{X}$ & & & & \\
\hline 5 & Dorsa Brevia & -72 & 280 & 1300 & $\mathbf{x}$ & $\mathbf{X}$ & $\mathbf{X}$ & & $\mathbf{X}$ & \\
\hline 6 & Terra Cimmeria & -70 & 230 & 1000 & & $\mathbf{x}$ & $\mathbf{x}$ & $\mathrm{x}$ & $\mathbf{x}$ & \\
\hline 7 & Eridania Scopulus & -50 & 215 & 800 & $\mathbf{X}$ & $\mathbf{x}$ & $\mathbf{X}$ & $\mathbf{x}$ & $\mathbf{X}$ & \\
\hline 8 & Arcadia Planitia & 38 & 173 & 400 & $\mathbf{x}$ & & $\mathbf{X}$ & $\mathbf{x}$ & & \\
\hline 9 & Marotis Fossae & 45 & 85 & 600 & $\mathrm{x}$ & $\mathbf{x}$ & $\mathbf{x}$ & & & \\
\hline 10 & Marotis Fossae & 42 & 85 & 550 & $\mathbf{x}$ & $\mathbf{x}$ & $\mathbf{X}$ & & & \\
\hline 11 & Terra Sirenum & -44 & 166 & 1000 & & $\mathbf{X}$ & $\mathrm{X}$ & $\mathbf{x}$ & & $?$ \\
\hline
\end{tabular}

*See Figure 14.

periphery of a spherical cap. However, this scenario is still in its formative stages and lacks quantitative detail that can be tested.

Nevertheless, it is clear that any successful model for Tharsis tectonism should incorporate, as a constraint, compression of the lithosphere beneath that province and vicinity during Late Noachian to Early Hesperian time. We provisionally interpret the Coprates rise to be a Tharsis-related structure because of the reasonable correspondence between calculated principal stress trajectories and the trend of the rise. This interpretation lends credence to the idea that Thaumasia-related deformation represents an early (if not distinct) stage of Tharsis deformation [Frey, 1979].

Phillips et al. [1990] suggested the occurrence of early flexural uplift at Tharsis, which in their view might have produced concentric grabens. However, the few such structures observed appear to cut only the oldest rocks in the Thaumasia region. Thus, if such flexural uplift took place, it did so prior to the deformation associated with the south Tharsis ridge belt and later Tharsis faulting.

Syria Planum, at the crest of the Tharsis rise, lies some 2500 $\mathrm{km}$ west of the Coprates rise. During the time of contractional deformation of the south Tharsis ridge belt (Late Noachian and Early Hesperian), localized normal faulting, perhaps associated with uplift of Syria Planum, occurred in association with magmatism and volcanism there [Tanaka and Davis, 1988]. Volcanism also occurred in much of the south Tharsis ridge belt during this time [Scott and Tanaka, 1986]. Although it is not yet possible to determine whether volcanism and tectonism in these two regions were linked dynamically, both regions apparently were sites of high heat flow and active tectonism during Late Noachian and Early Hesperian time.

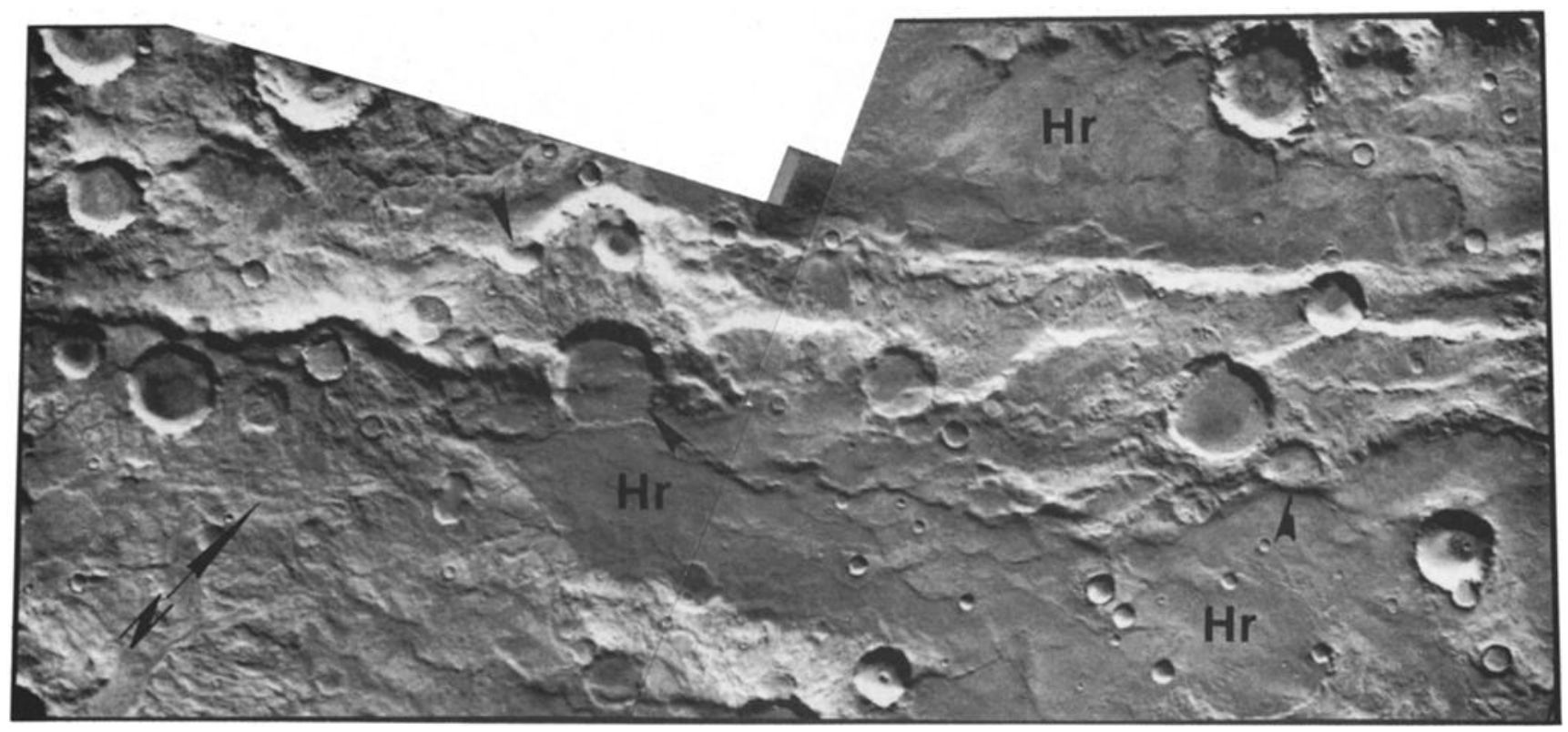

Figure 15. Part of Eridania Scopulus, about $1500 \mathrm{~km}$ east of Hellas Planitia in Terra Cimmeria (ridge 7 in Figure 14a and Table 3). This broad ridge structure, $800 \mathrm{~km}$ long by as much as $90 \mathrm{~km}$ wide, is crossed and bordered by high crested ridges and sinuous scarps. Note flanking low areas filled by wrinkle-ridged plains material (Hr). Three impact craters (arrows) show truncated portions of rims along edge of broad ridge. Mosaic of parts of Viking images $370 \mathrm{~S} 03,24$, and 26 centered at lat $51^{\circ} \mathrm{S}$, long $217^{\circ}$. 


\section{Other Ridge Systems}

Several other large ridges and ridge systems similar in topographic expression to the south Tharsis examples occur elsewhere on Mars. Their identification numbers are those in Figure 14 and Table 3. Some of these landforms are interpreted only provisionally as contractional structures here because the evidence for folding and structural uplift is more variable or speculative than that for the Coprates rise. Nevertheless many of these landforms may represent comparable or possibly degraded examples that should merit a closer examination.

The structures include (a) north-trending Phlegra Montes (3) and associated broad ridges west of Arcadia Planitia (4 and 8). The ridges are covered by degraded knobby terrain and Lower Hesperian plains material and commonly are bounded by scarps or wrinkle ridges, with relief as much as $2 \mathrm{~km}$. (b) The large north- to northeast-trending ridges cut by Mareotis Fossae on the western margin of Tempe Terra ( 9 and 10). Relief of these ridges as determined from photoclinometry exceeds $1 \mathrm{~km}$ (P.A. Davis, personal communication, 1992). Deformation that may be associated with ridge formation has been assigned an Early to Middle Noachian age [Scott and Dohm, 1990]. (c) North- to east-trending ridges and groups of large wrinkle ridges deform highland rocks south and east of Hellas basin (5-7 and 11). Most of these ridges have been mapped as Upper Noachian and Lower Hesperian structures [Scott and Tanaka, 1986; Greeley and Guest, 1987; Tanaka and Scott, 1987], similar in age to those in south Tharsis. A prominent example is $800-\mathrm{km}$-long Eridania Scopulus (Figure 15). (d) Northwest-trending

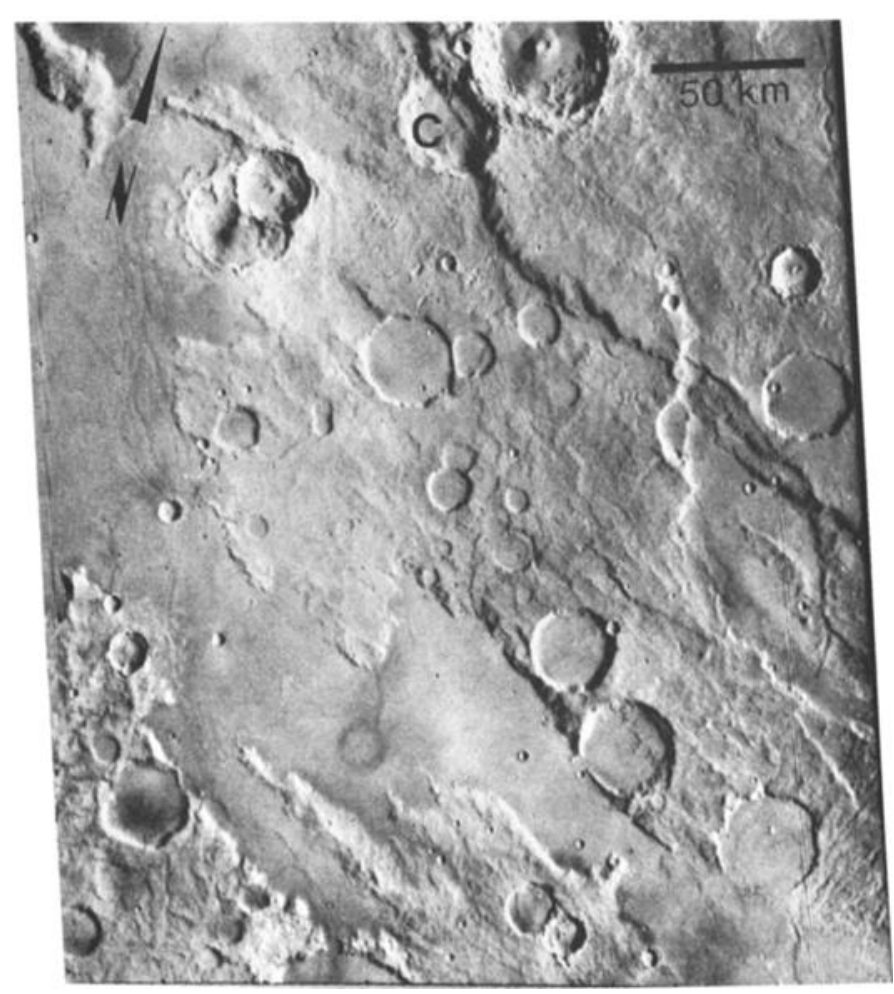

Figure 16. Northwest-trending sinuous scarps of Amenthes Rupes, in Noachian highland terrain about $800 \mathrm{~km}$ southeast of Isidis Planitia (ridge 2 in Figure 14a and Table 3); low areas embayed by smooth plains material. Impact crater (C), $35 \mathrm{~km}$ in diameter, has been shortened by about $5 \mathrm{~km}$ perpendicular to large crosscutting scarp. Viking image $379 \$ 46$ centered at lat $0^{\circ}$, long $250^{\circ}$.
Amenthes Rupes (2), southeast of Isidis Planitia, is made up of large sinuous scarps and crested ridges (Figure 16). These structures apparently formed during the Noachian, according to crater densities [Maxwell and McGill, 1988].

The Noachian and Early Hesperian ages of many large ridges on Mars predate and overlap the Late Noachian to Early Hesperian ages of most wrinkle ridges on the planet. Thus crustal and lithospheric buckling, and perhaips thrust faulting, may have been common on early Mars when the lithosphere was probably thinner, hotter, and weaker than at later times, and when horizontal compressive stresses in the crust and lithosphere were apparently large.

Acknowledgments. We thank David H. Scott for review of an early version of this manuscript. James M. Dohm provided many helpful comments based partly on his own detailed geologic mapping of the Thaumasia region. Reviews by Tom Watters and an anonymous referee significantly improved the manuscript and are gratefully acknowledged. M.T. Zuber helped clarify our thinking on compressional deformation of planetary lithospheres. This work was supported in part by grants NAGW-2347 (R.A.S.) and W15,814 (K.L.T.) from the NASA Planetary Geology and Geophysics Program.

\section{References}

Banerdt, W.B., R.J. Phillips, N.H. Sleep, and R.S. Saunders, Thick-shell tectonics on one-plate planets: Applications to Mars, J. Geophys. Res., 87, 9723-9733, 1982.

Banerdt, W.B., M.P. Golombek, and K.L. Tanaka, Stress and tectonics on Mars, in Mars, edited by H.H. Kieffer, B.M. Jakosky, C.W. Snyder, and M.S. Matthews, pp. 249-297, University of Arizona Press, Tucson, 1992.

Bindschadler, D.L., G. Schubert, and W.M. Kaula, Coldspots and hotspots: Global tectonics and mantle dynamics of Venus, $J$. Geophys. Res., 97, 13,495-13,532, 1992.

Bull, J.M., and R.A. Scrutton, Diffuse plate boundaries in the Indian and Atlantic Oceans (abstract), Eos Trans. AGU, 73, suppl., 508$509,1992$.

Chicarro, A.F., P.H. Schultz, and P. Masson, Global and regional ridge patterns on Mars, Icarus, 63, 153-174, 1985.

Cloetingh, S., and R. Wortel, Stress in the Indo-Australian plate, Tectonophysics, 132, 49-67, 1986.

Craddock, R.A., R. Greeley, and P.R. Christensen, Evidence for an ancient impact basin in Daedalia Planum, Mars, J. Geophys. Res., 95, 10,729-10,741, 1990.

Downs, G.S., P.J. Mouginis-Mark, S.H. Zisk, and T.W. Thompson, New radar-derived topography for the northern hemisphere of Mars, J. Geophys. Res., 87, 9747-9754, 1982.

Dunbar, J.A., and D.S. Sawyer, How preexisting weaknesses control the style of continental breakup, J. Geophys. Res., 94, 7278-7292, 1989.

Freund, L.B., and D.M. Barnett, A two-dimensional analysis of surface deformation due to dip-slip faulting, Bull. Seismol. Soc. Am., 66, 667-675, 1976. (Errata, Bull. Seismol. Soc. Am., 66, 2083-2084, 1976.)

Frey, H., Thaumasia: A fossilized early forming Tharsis uplift, $J$. Geophys. Res., 84, 1009-1023, 1979.

Golombek, M.P., J.B. Plescia, and B.J. Franklin, Faulting and folding in the formation of planetary wrinkle ridges, Proc. Lunar Planet. Sci., 21, 679-693, 1991.

Greeley, R., and J.E. Guest, Geologic map of the eastern equatorial region of Mars, U.S. Geol. Surv. Misc. Invest. Ser. Map, 1-1802-B, 1987.

Haneberg, W.C., Drape folding of compressible elastic layers-I. Analytical solutions for vertical uplift, J. Struct. Geol., 14, 713-721, 1992.

Johnson, A.M., Folding and faulting of strain-hardening sedimentary rocks, Tectonophysics, 62, 251-278, 1980.

King, G., and M. Ellis, The origin of large local uplift in extensional regions, Nature, 348, 689-693, 1990.

King, G.C.P., R.S. Stein, and J.B. Rundle, The growth of geological 
structures by repeated earthquakes 1 . Conceptual framework, $J$. Geophys. Res., 93, 13,307-13,318, 1988.

$\mathrm{Li}, \mathrm{V} . \mathrm{C} .$, Mechanics of shear rupture applied to earthquake zones, in Fracture Mechanics of Rock, edited by B.K. Atkinson, pp. 351-428, Academic, San Diego, Calif., 1987.

Lucchitta, B.K., A.S. McEwen, G.D. Clow, P.E. Geissler, R.B. Singer, R.A. Schultz, and S.W. Squyres, The canyon system on Mars, in Mars, edited by H.H. Kieffer, B.M. Jakosky, C.W. Snyder, and M.S. Matthews, pp. 453-492, University of Arizona Press, Tucson, 1992.

Lucchitta, B.K., N.K. Isbell, and A. Howington-Kraus, Topography of Valles Marineris: Implications for erosional and structural history, J. Geophys. Res., 99, 3783-3798, 1994.

Mandl, G., Tectonic deformation by rotating parallel faults: The "bookshelf" mechanism, Tectonophysics, 141, 277-316, 1987.

Mansinha, L., and D.E. Smylie, The displacement fields of inclined faults, Bull. Seismol. Soc. Am., 61, 1433-1440, 1971.

Martinod, J., and P. Davy, Periodic instabilities during compression or extension of the lithosphere 1. Deformation modes from an analytical pertubation method, J. Geophys. Res., 97, 1999-2014, 1992.

Masson, P., Contribution to the structural interpretation of the Valles Marineris-Noctis Labyrinthus-Claritas Fossae regions of Mars, Moon Planets, 22, 211-219, 1980.

Maxwell, T.A., Orientation and origin of ridges in the Lunae PalusCoprates region of Mars, Proc. Lunar Planet. Sci. Conf. 13th, Part 1, J. Geophys. Res., 87, suppl., A97-A108, 1982.

Maxwell, T.A., and G.E. McGill, Ages of fracturing and resurfacing in the Amenthes region, Mars, Proc. Lunar Planet. Sci. Conf., 18th, 701-711, 1988.

McGill, G.E., Geologic map of the Thaumasia quadrangle of Mars, U.S. Geol. Surv. Misc. Invest. Ser. Map, 1-1077, 1978.

Petroy, D.E., and D.A. Wiens, Historical seismicity and implications for diffuse plate convergence in the northeast Indian Ocean, J. Geophys. Res., 94, 12,301-12,319, 1989.

Phillips, R.J., N.H. Sleep, and W.B. Banerdt, Permanent uplift in magmatic systems with application to the Tharsis region of Mars, $J$. Geophys. Res., 95, 5089-5100, 1990.

Plescia, J.B., and R.S. Saunders, Tectonic history of the Tharsis region, Mars, J. Geophys. Res., 87, 9775-9791, 1982.

Plescia, J.B., L.E. Roth, and R.S. Saunders, Tectonic features of southeast Tharsis (abstract), Reports of Planetary Geology Program, 1979-1980, 68-70, NASA Tech. Memo., 81776, 1980.

Roth, L.E., G.S. Downs, and R.S. Saunders, Radar altimetry of south Tharsis, Mars, Icarus, 42, 287-316, 1980.

Saunders, R.S., L.E. Roth, G.S. Downs, and G. Schubert, Early volcanic-tectonic province: Coprates region of Mars (abstract), Reports of Planetary Geology Program, 1979-1980, 74-76, NASA Tech. Memo., 81776, 1980.

Schultz, R.A., Assessment of global and regional tectonic models for faulting in the ancient terrains of Mars, J. Geophys. Res., 90, 78497860,1985 .

Schultz, R.A., Strike-slip faulting of ridged plains near Valles Marineris, Mars, Nature, 341, 424-426, 1989.

Schultz, R.A., Structural development of Coprates Chasma and westem Ophir Planum, Valles Marineris rift, Mars, J. Geophys. Res., 96, 22,777-22,792, 1991

Schultz, R.A., and H.V. Frey, Topography and structure of Valles Marineris, Mars (abstract), Fourth International Conference on Mars, 183-184, NASA, Tucson, Ariz., 1989.

Schultz, R.A., and H.V. Frey, A new survey of multiring impact basins on Mars, J. Geophys. Res., 95, 14,175-14,189, 1990.

Scott, D.H., and J.M. Dohm, Faults and ridges: Historical development in Tempe Terra and Ulysses Patera regions of Mars, Proc. Lunar Planet. Sci. Conf., 20th, 503-513, 1990.

Scott, D.H., and K.L. Tanaka, Geologic map of the western equatorial region of Mars, U.S. Geol. Surv. Misc. Invest. Ser. Map, I-1802-A, 1986.

Squyres, S.W., D.G. Jankowski, M. Simons, S.C. Solomon, B.H. Hager, and G.E. McGill, Plains tectonism on Venus: The deformation belts of Lavinia Planitia, J. Geophys. Res., 97, 13,579-13,599, 1992.

Stein, R.S., G.C.P. King, and J.B. Rundle, The growth of geological structures by repeated earthquakes 2 . Field examples of continental dip-slip faults, J. Geophys. Res., 93, 13,319-13,331, 1988.
Suppe, J., and C. Connors, Critical taper wedge mechanics of fold-andthrust belts on Venus: Initial results from Magellan, J. Geophys. Res., 97, 13,545-13,561, 1992.

Tanaka, K.L., The stratigraphy of Mars, Proc. Lunar Planet. Sci. Conf. 17th, Part 1, J. Geophys. Res., 9l, suppl., E139-E158, 1986.

Tanaka, K.L., and P.A. Davis, Tectonic history of the Syria Planum province of Mars, J. Geophys. Res., 93, 14,893-14,917, 1988.

Tanaka, K.L., and M.P. Golombek, Martian tension fractures and the formation of grabens and collapse features at Valles Marineris, Proc. Lunar Planet. Sci. Conf., 19th, 383-396, 1989.

Tanaka, K.L., and D.H. Scott, Geologic map of the polar regions of Mars, U.S. Geol. Surv. Misc. Invest. Ser. Map, I-1802-C, 1987

Tanaka, K.L., M.P. Golombek, and W.B. Banerdt, Reconciliation of stress and structural histories in the Tharsis region of Mars, $J$. Geophys. Res., 96, 15,617-15,633, 1991.

Thomas, P.G., and P. Allemand, Quantitative analysis of the extensional tectonics of Tharsis bulge, Mars: Geodynamic implications, $J$. Geophys. Res., 98, 13,097-13,108, 1993.

U.S. Geological Survey, Topographic maps of the western, eastern equatorial, and polar regions of Mars, U.S. Geol. Surv. Misc. Invest. Ser. Map, I-2030, 1989.

Watters, T.R., Thin and thick-skinned deformation in the Tharsis region of Mars (abstract), Reports of Planetary Geology Program, 1986, NASA Tech. Memo., 89801, 481-483, 1987.

Watters, T.R., Origin of periodically spaced wrinkle ridges on the Tharsis plateau of Mars, J. Geophys. Res., 96, 15,599-15,616, 1991. (Correction, J. Geophys. Res., 96, 22,829-22,832, 1991.)

Watters, T.R., A system of tectonic features common to Earth, Mars, and Venus, Geology, 20, 609-612, 1992.

Watters, T.R., Compressional tectonism on Mars, J. Geophys. Res., 98, 17,049-17,060, 1993.

Watters, T.R., and T.A. Maxwell, Orientation, relative age, and extent of the Tharsis plateau ridge system, J. Geophys. Res., 91, 8113$8125,1986$.

Weissel, J.K., R.N. Anderson, and C.A. Geller, Deformation of the Indo-Australian plate, Nature, 287, 284-291, 1980.

Wiens, D.A., S. Stein, C. DeMets, R.G. Gordon, and C. Stein, Plate tectonic models for Indian Ocean "intraplate" deformation, Tectonophysics, 132, 37-48, 1986.

Wise, D.U., M.P. Golombek, and G.E. McGill, Tharsis province of Mars: Geologic sequence, geometry, and a deformation mechanism, Icarus, 38, 456-472, 1979.

Zuber, M.T., Compression of oceanic lithosphere: An analysis of intraplate deformation in the central Indian Basin, J. Geophys. Res. 92, 4817-4825, 1987a.

Zuber, M.T., Constraints on the lithospheric structure of Venus from mechanical models and tectonic surface features, Proc. Lunar Planet. Sci. Conf. 17th, Part 2, J. Geophys. Res., 92, suppl., E541E551, 1987b.

Zuber, M.T., Wrinkle ridges, reverse faulting, and the depth penetration of lithospheric stress in Lunae Planum, Mars (abstract), Lunar Planet. Sci., XXIV, 1589-1590, 1993.

Zuber, M.T., and L.L. Aist, The shallow structure of the Martian lithosphere in the vicinity of the ridged plains, J. Geophys. Res., 95, $14,215-14,230,1990$.

Zuber, M.T., and E.M. Parmentier, Horizontal shortening of a variable thickness lithosphere and the origin of mountain belt-fringed plateaus (abstract), Eos Trans. AGU, suppl., 546, 1993.

Zuber, M.T., D.E. Smith, S.C. Solomon, D.O. Muhleman, J.W. Head, J.B. Garvin, J.B. Abshire, and J.L. Bufton, The Mars Observer laser altimeter investigation, J. Geophys. Res., 97, 7781-7797, 1992.

R.A. Schultz, Geomechanics-Rock Fracture Group, Department of Geological Sciences, Mackay School of Mines/172, University of Nevada, Reno, NV 89557-0138.

K.L. Tanaka, U.S. Geological Survey, 2255 North Gemini Drive, Flagstaff, AZ 86001.

(Received March 1, 1993; revised January 21, 1994; accepted January 31, 1994.) 